In Submerged Landscapes of the European Continental Shelf: Quaternary Paleoenvironments. Chap. 2. pp 11-49

2017

Eds Nicholas C. Flemming , Jan Harff, Delminda Moura , Anthony

Burgess, Geoffrey N. Bailey

ISBN 9781118922132

http://dx.doi.org/10.1002/9781118927823.ch2

http://archimer.ifremer.fr/doc/00391/50263/

(c) 2017 John Wiley \& Sons, Ltd. All rights reserved.

\title{
Sea Level and Climate
}

\author{
Harff Jan ${ }^{1}$, Flemming Nicholas $C^{2}$, Groh Andreas ${ }^{3}$, Hunicke Birgit ${ }^{4}$, Lericolais Gilles ${ }^{5}$,

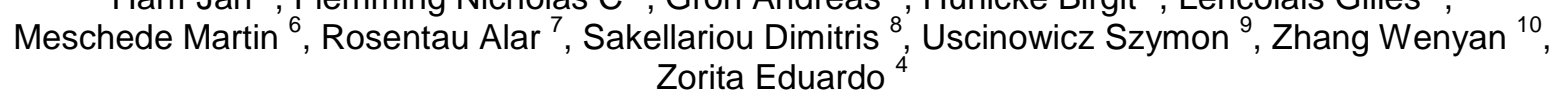

${ }^{1}$ University of Szczecin, Szczecin, Poland

${ }^{2}$ National Oceanography Centre, Southampton, UK

${ }^{3}$ Helmholtz Centre Potsdam, GFZ German Research Centre for Geosciences, c/o DLR Oberpfaffenhofen, Wessling, Germany

${ }_{5}^{4}$ Helmholtz Centre Geesthacht, Geesthacht, Germany

${ }^{5}$ IFREMER, DAEI, Issy-les-Moulineaux, France

${ }^{6}$ University of Greifswald, Greifswald, Germany

${ }^{7}$ University of Tartu, Department of Geology, Tartu, Estonia

8 Institute of Oceanography, Hellenic Centre for Marine Research, Anavyssos, Greece

${ }^{9}$ Polish Geological Institute - National Research Institute, Branch of Marine Geology, Gdańsk, Poland

${ }^{10}$ MARUM - Center for Marine Environmental Sciences, University of Bremen, Bremen, Germany

\begin{abstract}
:
This chapter gives an overview of the environmental changes to the European shelf and its marginal seas during the Late Pleistocene to the Middle Holocene. It first explains the regional tectonics of Europe. The age of the consolidation of the basement together with the plate tectonic setting serves as the main parameters determining coastal formation. Next, the chapter reviews the fluctuation of glacial and interglacial stadia as an effect of orbital parameters of the Earth around the Sun. In addition, it examines eustatic change during the Last Glacial Cycle (LGC). The chapter also describes the development of the Baltic Sea, the North Sea and the Atlantic shelf, based on numerical sea-level scenarios constrained by observational data. Finally, it explains the basics of the ECHO-G global climate model, together with an overview of Late Holocene changes in European climate with special attention to wind forces.
\end{abstract}

Keywords: Baltic Sea, climate change, coastal formation, environmental changes, European continental shelf, eustatic change, Late Pleistocene, Middle Holocene, sea level 


\section{Introduction}

1 fter two decades of research on the archaeology, climate and environment of the drowned landscapes of local and subregional parts of the European continental shelf, one of the first tasks of the SPLASHCOS Action was to attempt a comprehensive and integrated view of the shelf and its marginal seas, including the human component. The way in which the changing conditions on the continental shelf determined where humans lived, and the survival or destruction of their archaeological remains, will be discussed in later chapters. However, everything that follows is determined and influenced by the changing climate and changing sea level, and this will be analyzed first.

The European continental shelf was subject to dramatic environmental changes after the last glaciation. Continental ice sheets disappeared and melt water and new drainage systems shaped the periglacial landscape. Dammed meltwater lakes filled morphological depressions. Sea level rose and the transgression flooded large parts of the continental shelf, turning former freshwater 
lakes into brackish-marine ones. In this chapter we will give an overview of the environmental changes to the European shelf and its marginal seas during the Late Pleistocene to the Middle Holocene. The driving forces of these environmental changes are complex and interdependent. The most important variables are climatically-controlled eustatic sea-level change and vertical dislocation of the Earth's crust. Eustatic change is to be regarded mainly as a function of the change of ice/water volume during the glacial cycles and of steric effects (thermal expansion or contraction of sea water due to changing temperature) during the Holocene. Vertical crustal movement expresses variable rates of subsidence and uplift induced by lithospheric dynamics, as well as more localized tectonic movements. Superimposed on these effects of internal geodynamic forces (expressed within the tectonic regionalization of Europe) are external forces: loading and unloading of the crust by ice and water. These changes in load have to be considered as an effect of global climate. Climatic fluctuations in the Earth's history cause accumulation of inland ice shields during cold (glacial) periods and a draining of melt water to marine basins during warm (interglacial) periods. In the context of relative sea-level change, depending on the tectonic setting, but also on the geographic position, three subregions can be distinguished for Europe (Fig. 2.1): the Baltic basin, the North Sea and Atlantic shelf, and the Mediterranean basin together with the Black Sea.

The first section of this chapter is devoted to the regional tectonics of Europe. The age of the consolidation of the basement together with the plate tectonic setting will serve here as the main parameters determining coastal formation.

The next section reviews the fluctuation of glacial and interglacial stadia as an effect of orbital parameters of the Earth around the Sun. These processes are

Fig. 2.1 Geographical overview of Europe including shelf areas, and marginal sea sub-regions to be treated separately in this chapter.

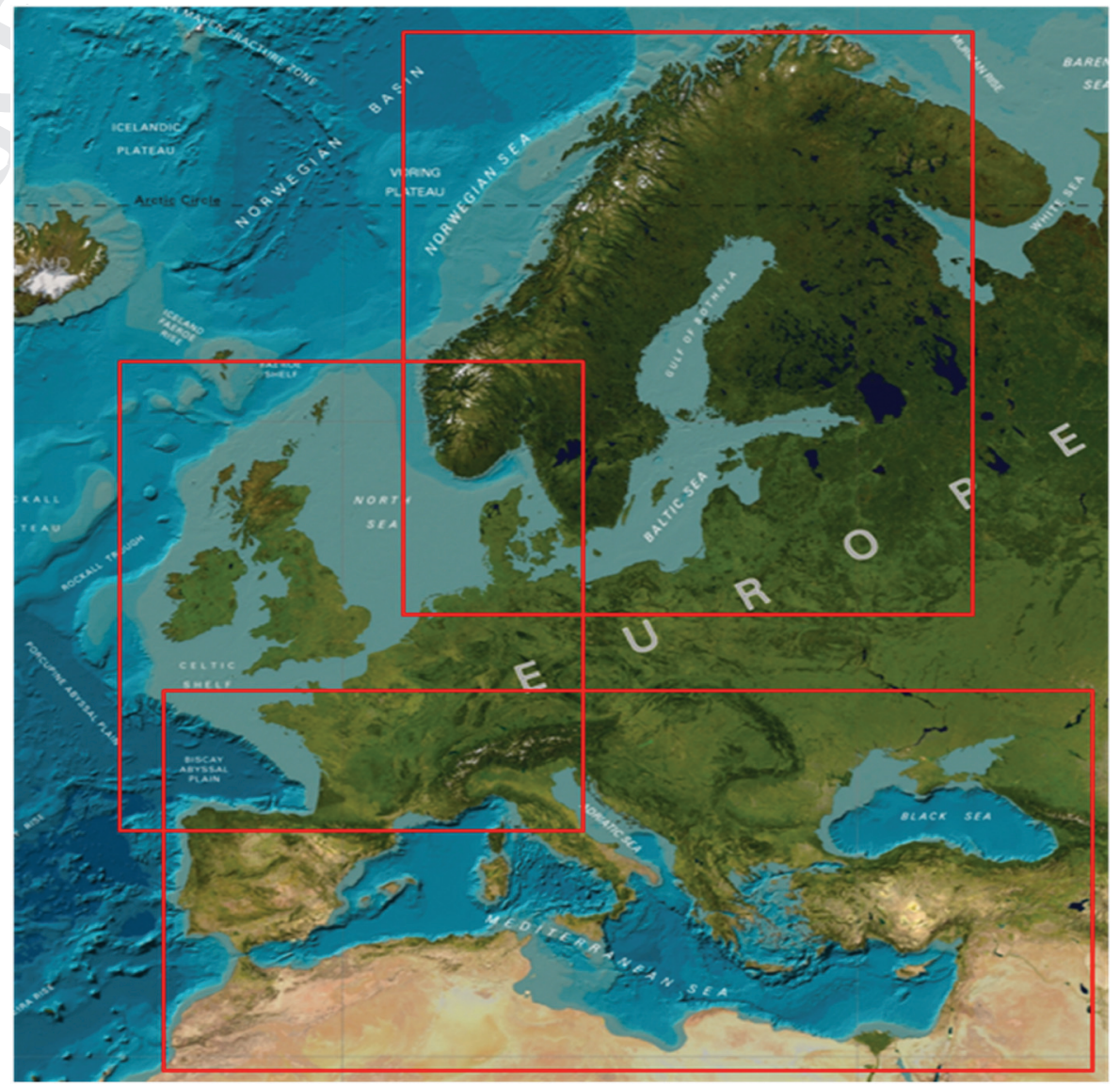


interpreted as driving forces of ice-sheet dynamics and eustatic fluctuations. We will examine, in particular, eustatic change during the Last Glacial Cycle (LGC). As recent human populations have been mainly affected by postglacial sea-level rise and isostatic effects of the decaying ice sheet, the last deglaciation will be highlighted in particular. We present a regional model, which classifies European coastal regions according to whether they are regions of relative sea-level rise (sea transgression) or sea-level fall (regression of the sea). In isostatically and tectonically stable or subsiding coastal areas the postglacial paleogeographic history is mainly a result of sea transgression. Only if the rate of uplift of the crust exceeds the eustatic sea-level rise does a regression of the sea take place, resulting in the emergence of land formerly covered by the sea. This interplay of loading and its effect on relative sea-level change will be explained by a numerical model, before addressing regional paleogeographic reconstructions.

The next sections describe the development of the Baltic Sea, the North Sea and the Atlantic shelf, based on numerical sea-level scenarios constrained by observational data. In semi-enclosed and partly enclosed basins such as the Baltic Sea and the Black Sea basins the models cannot be linked to global sea-level scenarios. Here the water level is controlled by the drainage of the surrounding land including the inflow of melt water from decaying ice sheets. Therefore, the subregional paleogeographic reconstructions given for these regions are derived from the interpretation of sedimentological proxy data and mapping of paleoshorelines.

In areas of inundation the migrating shoreline reworks the surface of the paleolandscape. For times of relatively rapid sea-level rise - as during the Late Pleistocene and Early Holocene - we find that shorelines tend to preserve their former shape better than in periods of slow sealevel rise (Late Holocene) when hydrographic forcing reworked intensely the substrate of the coastal zone and eventually destroyed many archaeological sites.

For integrated modeling approaches of these processes aimed at predicting where human settlements are likely to have been preserved, information about the atmospheric forcing of coastal dynamics is needed. The data can be derived from long-term climate modeling. In the last section of this chapter, we explain the basics of the ECHO-G global climate model, together with an overview of Late Holocene changes in European climate with special attention to wind forces. In the second part of this section, we give an overview of long-term coastal morphogenesis, using the southern Baltic Sea sandy barrier coast as an example.

\section{Tectonic and Geological Setting of Europe with Special Reference to the Shelf and Marginal Seas}

The continental crust of Europe can be subdivided into four different structural units which differ in age and tectonic history (Fig. 2.2). The oldest complex is the East European platform representing an old cratonic structure mainly built in Proterozoic times. This complex formed the continent 'Baltica', which is taken as an independent tectonostratigraphic unit in most paleogeographic reconstructions of the Late Proterozoic and Early Paleozoic (e.g. Lawver et al. 2009). Various Phanerozoic orogenic events added crustal provinces to this continental plate and it became part of the Eurasian plate. The crustal provinces get younger in sequence from north to south.

\section{Proto-Europe}

The oldest crustal units of Europe belong to the East European platform which comprises the Baltic Shield, the Russian platform and the Ukrainian Shield (Fig. 2.2). These units mainly consist of highly metamorphosed and igneous Precambrian rocks. The southern boundary of Baltica is clearly confined by the Teisseyre-Tornquist Zone running in a southeast-northwest direction from the Carpathians into the area of the North Sea. In the northwestern part, this zone is split into a northern branch, named the Sorgenfrei-Tornquist Zone, and a southern branch. This zone is one of the most important suture zones in Europe. 
Fig. 2.2 Tectonostratigraphic units of Europe. Red colors $=$ Precambrian basement; green colors $=$ Caledonian orogeny; blue colors = Variscan orogeny; yellow colors $=$ Alpine orogeny: $\mathrm{MGCZ}=$ Mid-German Crystalline Zone. From Meschede (2015), modified and supplemented after Kossmat (1927), Franke (1989), Martínez Catalán et al. (2007) and others.

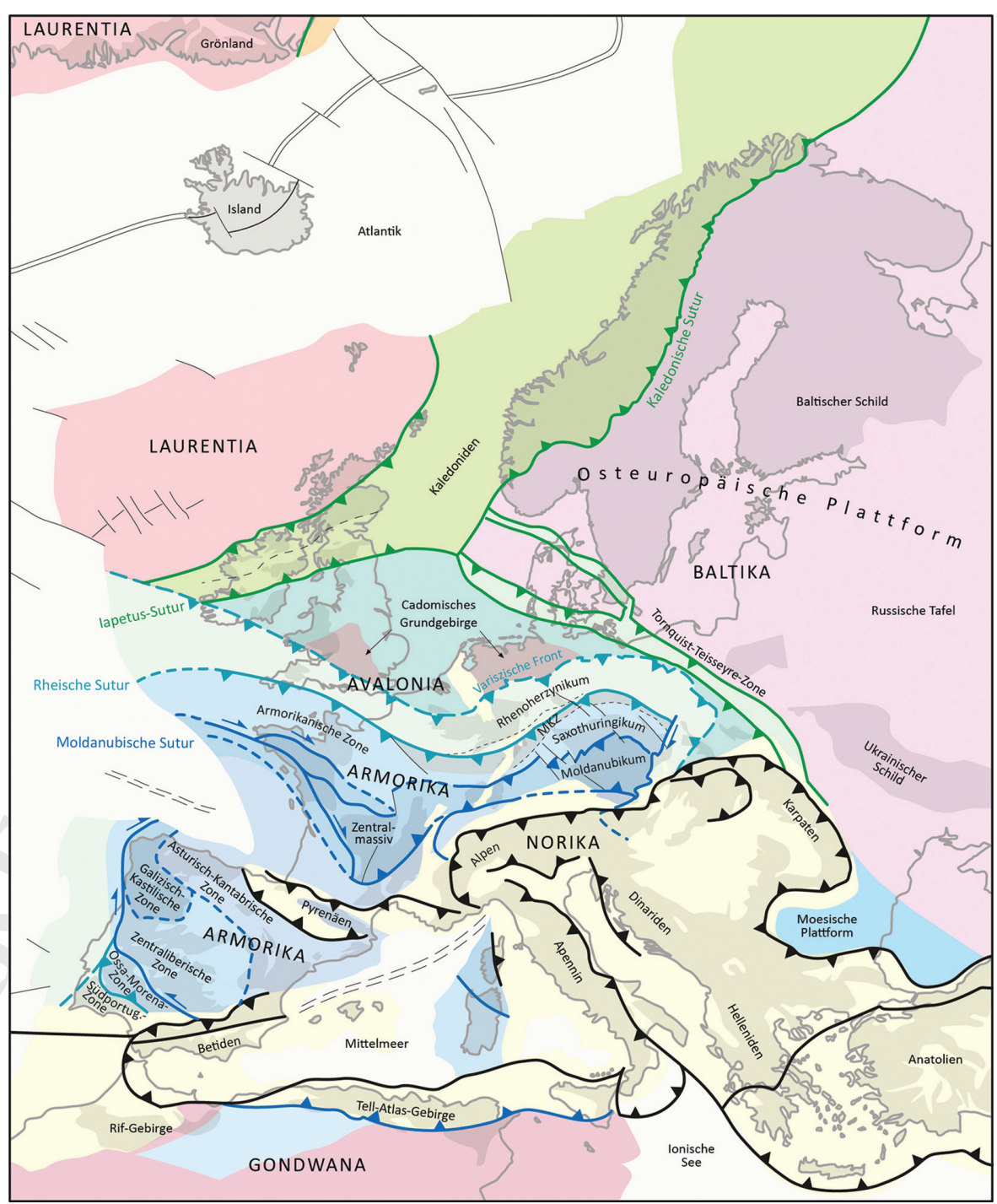

Baltica and Laurentia collided in Ordovician and Silurian times forming the Caledonian mountain range. Between the two continents the Iapetus Ocean opened in the Late Precambrian and was completely subducted by the end of the Ordovician. Today a deep crustal level of the collisional orogen is exposed because of intense erosion and isostatic rebound since the Caledonian orogeny. A small continental block named Avalonia (after the peninsula of Avalon on the Canadian island, Newfoundland) was accreted as a terrane to Baltica during the Ordovician before the collision of Laurentia and Baltica. Between Baltica and Avalonia, the Tornquist Ocean, a small lateral branch of the Iapetus Ocean, the Atlantic Ocean, the predominant part of Laurentia is today situated on the American side of the Atlantic. 
was closed. Both Baltica and Avalonia collided in the Ordovician as a unit forming with Laurentia the new and bigger continent Laurussia. Avalonia had originally been part of Gondwana. It was separated from this large continental mass in the south during the Early Paleozoic and subsequently migrated towards the north as a terrane. As the result of collision with a continent, it accreted to the continental margin. Avalonia comprises Newfoundland located today on the American side of the Atlantic Ocean, the southern parts of Great Britain and Ireland, the basement of northern Germany today covered by younger sediments and the Variscan units of the Rhenohercynian (Rhine-Harz mountains zone). Avalonia is connected to Baltica along the TeisseyreTornquist Zone.

The Baltic Sea is not an ocean in the sense of plate-tectonic definitions. It is completely underlain by continental crust which mostly belongs to the East European platform. The maximum depth of the Baltic Sea is about $460 \mathrm{~m}$ (Landsort Deep) compared to more than $5000 \mathrm{~m}$ in the oceanic crust realms of the Mediterranean Sea and more than $2000 \mathrm{~m}$ in the Black Sea. The area south of the Teisseyre-Tornquist Zone belongs to the continental crust added to Europe during the Caledonian orogeny.

The most recent tectonic movements in the Baltic Sea region were induced by the glaciation of the Northern Hemisphere in the Quaternary. The repeated emergence and removal of a kilometer-thick ice cover led to isostatic rebound, which triggered earthquakes mainly occurring at normal faults. However, the strike-slip characteristics of recent earthquakes shown by fault-plane-solutions (e.g. the 2008 earthquake of Malmö, Sweden, magnitude 4.7) may indicate a reactivation of faults in the TeisseyreTornquist Zone.

\section{Meso-Europe}

The Variscan (or Hercynian) mountain range comprises the southern part of Avalonia and large parts of Armorica, an extensively-stretched terrane composed of several tectonic units and different rocks of various ages. These units are Iberia, the Armorican Massif, the French Central Massif, most parts of the Vosges and the Black Forest, and the Bohemian Massif as well as the Saxothuringian unit in the sense of Kossmat (1927; also see page $[\mathrm{xxx}])$.

The Variscides are a multiply subdivided mountain range across Europe which was mainly formed in Devonian and Carboniferous times. As with the Caledonides, only a part of this mountain range is located today in Europe while the other, bigger part continues as the Appalachian range on the western side of the Atlantic Ocean. In Middle Europe the Variscides are subdivided into three units, from north to south the Rhenohercynian, the Saxothuringian, and the Moldanubian (Kossmat 1927). The northernmost part belongs to Avalonia, but the main portion of the Variscides is part of Armorica which was also once connected to Gondwana. Armorica rifted away from Gondwana during the Silurian and migrated independently towards the north. During the Variscan orogeny, Armorica was welded to Avalonia, which at that time was already part of Laurussia (see page $[\mathrm{xxx}]$ ). The Rheic Ocean between Avalonia and Armorica was closed during the Variscan orogeny. Sediments of the Rhenohercynian were deposited at the northern margin of this ocean where an area with thinned continental crust was formed at the passive continental margin of Laurussia (former Avalonia). The Rheic Ocean is subducted beneath Armorica. The volcanic arc at the northern boundary of Armorica belongs to the Saxothuringian. It is represented today in the Mid-German Crystalline Zone (MGCZ - see Fig. 2.2). Sediments of the Saxothuringian are made up of similar sedimentary facies as the Rhenohercynian. The Moldanubian Zone is characterized by highly metamorphosed basement rocks and a long-lasting Cambrian to Devonian carbonate platform (named the Teplá-Barrandian). Both the Saxothuringinan and Moldanubian are part of Armorica, which is bordered in the south by the Moldanubian suture zone. In the south and south-east, some units exist which probably did not disconnect completely from Gondwana during the Variscan orogeny. A part of these terranes with strong affinity to Gondwana is the Alpine terrane Norica. The formation of the Variscan mountain range marks the combination of all the large continental lithospheric plates into the supercontinent Pangea. 


\section{Neo-Europe}

The youngest affiliation of crustal provinces to the Eurasian continent was the Alpine mountain range with its southern-associated microplates. However, the interpretation, number and shape of the microplates involved in the Alpine orogeny is still under debate. In this overview, the Adriatic-Apulian plate and the Anatolian plate are subdivided. Besides the Alps, the mountain range formed during the Alpine orogeny comprises also the Carpathians, the Dinarides, the Hellenides, the Apennines, the Tell-Atlas mountains, the Betic Cordillera and the Pyrenees (Fig. 2.2). The Alpine orogeny started at the end of the Cretaceous and is still not completed.

The Mediterranean is thus a remnant ocean in its eastern part, where the oldest oceanic crust which is still in place can be observed (Müller et al. 2008). The oceanic crust was formed in the Tethys Ocean during the Triassic. The western part of the Mediterranean consists of young oceanic crust which formed when Corsica and Sardinia rifted away from Europe during the Miocene. The Black Sea also contains part of the trapped oceanic crust from the Tethys Ocean. With an age of Early Cretaceous it is slightly younger than in the eastern Mediterranean.

\section{Quaternary Climate and Sea-level Change}

The global evolution of climate during the Quaternary has been analyzed and described by numerous authors, among them Brooks (1926), Milankovitch (1930), Crowley and North (1991) and Ruddiman (2008). In this section we review mainly the results published by Rahmstorf (2002), Plant et al. (2003), Carlson (2011), Wanner et al. (2011) and Grant et al. (2012).

The climate history of the Quaternary is considered an alternation of glacial and interglacial periods. Milankovitch (1930) described mathematically the periodical variation of the Earth's orbital parameter around the sun as the cause of changes in insolation and consequently external energy supply to the Earth. According to this theory (Berger \& Loutre 1991) it is

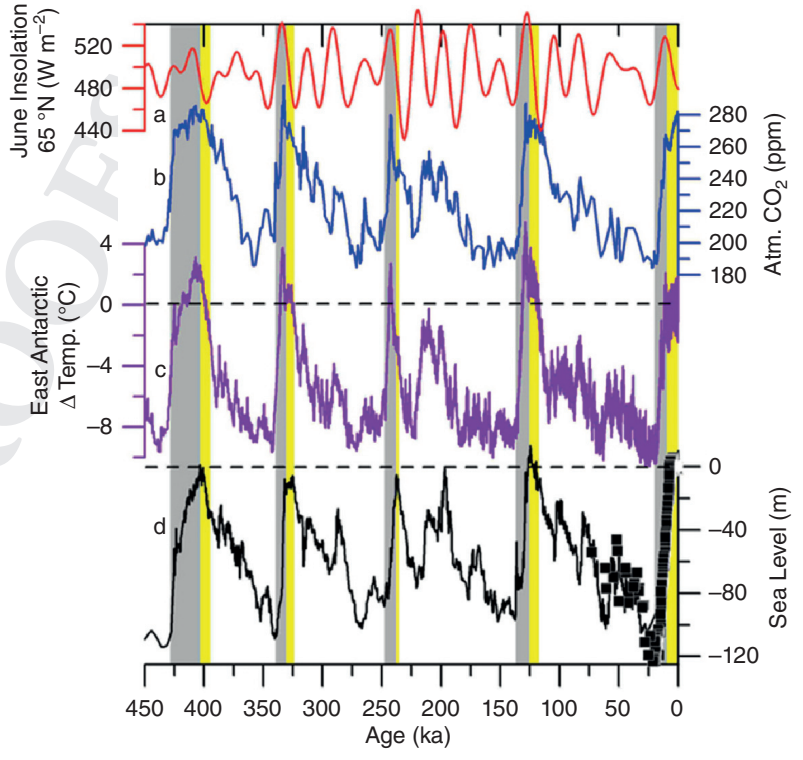

Fig. 2.3 Climate and sea level of the last $450 \mathrm{kyr}$ after Carlson (2011); (a) June insolation at $65^{\circ} \mathrm{N}$ (Berger \& Loutre 1991); (b) Atmospheric $\mathrm{CO}_{2}$ concentrations from Antarctic ice cores (Siegenthaler et al. 2005); (c) East Antarctic change in temperature (dashed line = present-day temperature) after Jouzel et al. (2007); (d) Sea-level records from the Red Sea (black line), black squares = individual sea-level estimates, dashed line = present-day sea level (Clark et al. 2009; Rohling et al. 2009), gray bars = deglaciations; yellow bars $=$ interglaciations.

assumed that cyclic changes in boreal summer insolation are responsible for the cyclicity in the build-up of continental ice shields during the glacial periods and their interglacial decay. This process leads to a cyclic redistribution of water from the ocean to the continents where it is stored during the glacial periods as ice, and from where it returns by melting during the interglacials to the oceanic (and terrestrial) basins. This interdependence between boreal insolation, continental ice volume and global sea level may - according to Carlson (2011) - be further amplified, since ocean circulation and atmospheric $\mathrm{CO}_{2}$ concentration may also be influenced by the Milankovitch Cycles (compare Fig. 2.3). Atmospheric temperature reconstructions are mainly based on oxygen isotope proxies from Antarctic and Greenland ice cores, whereas sea-level changes can be traced back by radiometrically dated corals (Lambeck 
\& Chappell 2001; Waelbroeck et al. 2002) or changes in the isotopic signature of planktonic foraminifera shells of the semi-enclosed basins (Red Sea, Mediterranean Sea) reflecting changes in paleo-salinities because of periodic isolation from ocean circulation (Siddall et al. 2004; Rohling et al. 2009; Grant et al. 2012).

In particular, studies of oxygen isotopes of Red Sea and Mediterranean Sea foraminifera have led to a detailed picture of global sea-level change during the LGC. Grant et al. (2012) have developed a probabilistic model of the LGC sea-level change based on a statistical analysis of empirical data including an estimation of errors from different sources. The authors show that the timing of ice-volume fluctuations (within a centennial response time) correlates well with the Antarctic and Greenland climate. In Fig. 2.4 the relative sea-level probabilistic model $\left(\mathrm{RSL}_{\mathrm{Pmax}}\right)$, RSL data and the first derivative (as an expression of sea-level change) are depicted. Time spans of rapid sea-level changes (rise) are marked by red arrows. It is remarkable that rates of sea-level rise during icevolume reduction phases have reached more than $1.2 \mathrm{~m}$ per century.

The sea-level curve in Fig. 2.4 reveals a cyclic pattern of sea-level dynamics during the last glaciation which can be roughly correlated with the boreal summer insolation (Berger \& Loutre 1991) supporting the theory of a cause-and-effect relation, but climate variations in higher resolution need a more complex interpretation. In Fig. 2.5, sea surface temperature (SST) as reconstructed from sediment proxies for the southern Atlantic Ocean and oxygen isotope signatures for the Greenland ice for Marine Isotope Stage 3 (MIS 3) are depicted. There is obviously a cyclic change between warmer and colder periods, whereby the driving forces have to be sought in the nonlinear processes of ocean circulation (Rahmstorf 2002). The appearance of warm events within the Dansgaard-Oeschger (D-O) fluctuations during the LGC follows according to Alley et al. (2001) a periodicity of ca. 1500 years (and its multiples 3000 and 4500 years) which is mainly explained by changes in the North Atlantic overturning. Heinrich events play the role of the cold counterparts of D-O events with an irregular return period of about 10,000 years. Ice rafted debris (IRD) in the marine North Atlantic sediments points to lines of evidence for massive iceberg discharges from the Laurentian ice sheet during these cold periods. The occurrence is mainly explained by a shift in the circulation pattern of the northern Atlantic so that the North

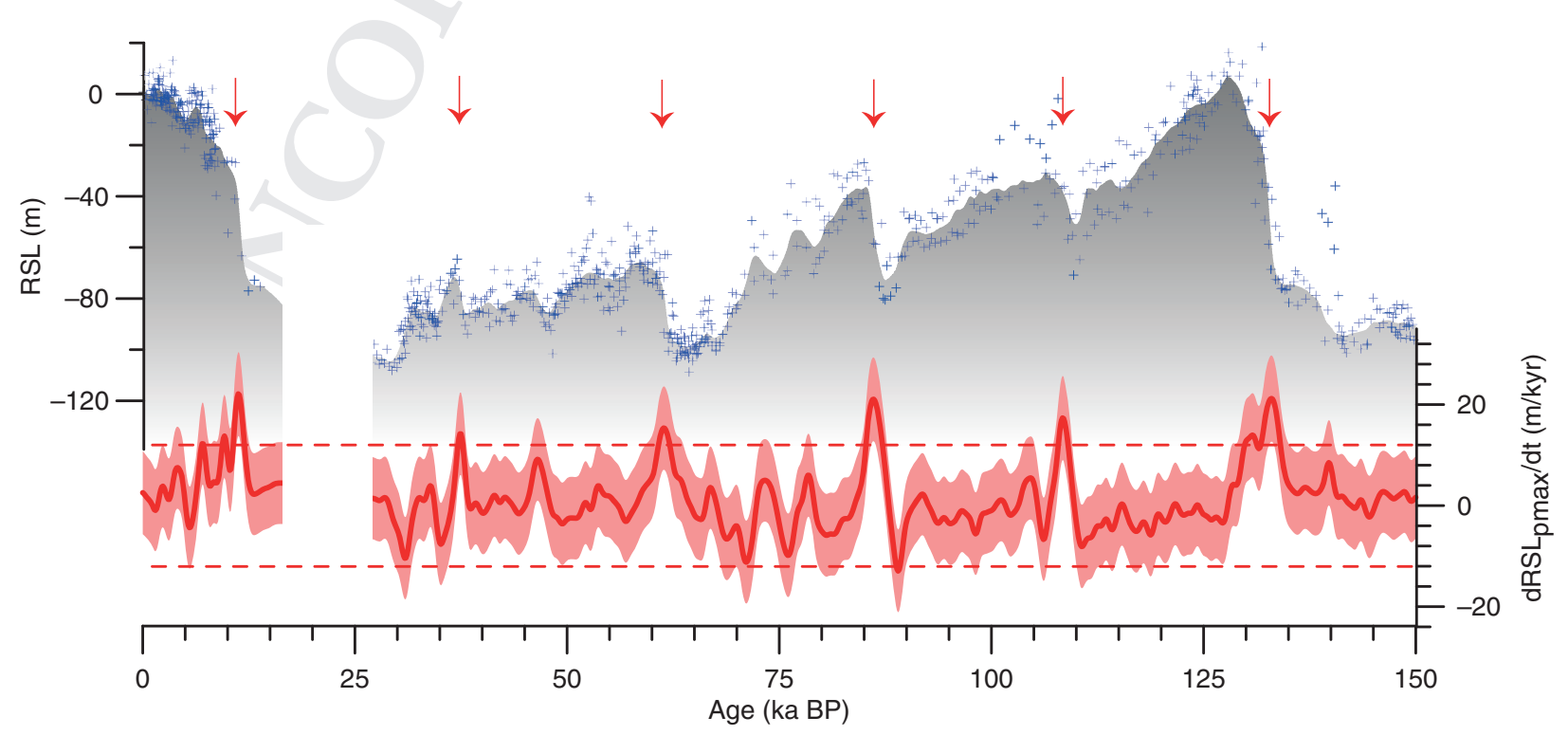

Fig. 2.4 Stochastic relative sea-level model ( $R S L_{\text {Pmax }}$, gray shading), RSL data (blue crosses) and probability maximum of the first derivative of RSL (red) with 95\% confidence interval (pink shading). After Grant et al. (2012). Rates of sea-level change of $+12 \mathrm{~m} / \mathrm{kyr}$ and $-8 \mathrm{~m} / \mathrm{kyr}$ are indicated (dashed lines). Red arrows mark peaks in sea-level rises of more 12 than $12 \mathrm{~m} / \mathrm{kyr}$. 


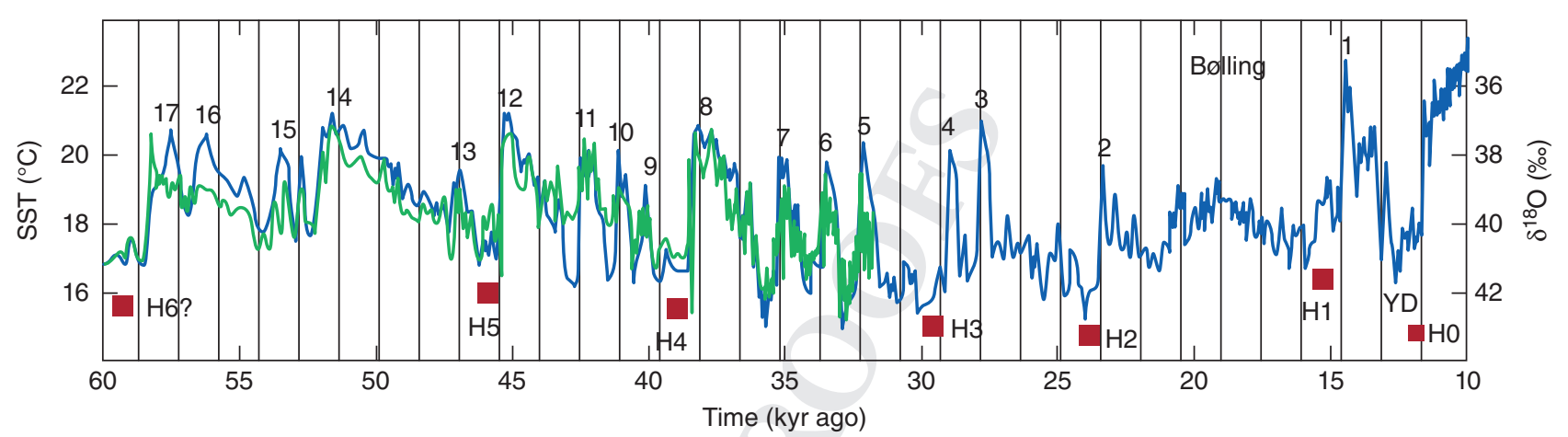

Fig. 2.5 Temperature reconstructions from ocean sediments and Greenland ice. Proxy data from the subtropical Atlantic (green) and from the Greenland ice core GISP2 (blue) show several Dansgaard-Oeschger (D-0) warm events (numbered). The timing of Heinrich events is marked in red. Gray lines at intervals of 1,470 years illustrate the tendency of D-O events to occur with this spacing, or multiples thereof. Rahmstorf (2002).

Atlantic Deep Water (NADW) formation is interrupted and Antarctic water advances into the entire deep North Atlantic basins.

During the time span between 26,500 and 19,00020,000 years ago, the last glaciation reached its maximum in continental ice extension. This time span - the Last Glacial Maximum (LGM) — is linked to an extreme impact of ice sheets on the Earth's climate and surface morphogenesis, resulting in extreme droughts, desertification, and exposure of most of today's continental shelf area due to a dramatic fall in sea level.

After the LGM, climatic change brought about the last deglaciation, extending from $20 \mathrm{ka} \mathrm{BP}$ to $6 \mathrm{ka}$ BP whereby the retreat of all Earth's ice sheets caused a sealevel rise of $125 \mathrm{~m}$ to $130 \mathrm{~m}$ (Fig. 2.6). Figure 2.6 (f) depicts the changes in sea level with extreme values involving many meters of sea-level rise over time spans of centuries. The first increase in the rate of sea-level rise at $20 \mathrm{ka} \mathrm{BP}$ to $19 \mathrm{ka} \mathrm{BP}$ to $\sim 1.4 \mathrm{~cm} /$ year followed shortly after the initial rise in boreal summer insolation (Fig. 2.3a) (Yokoyama et al. 2000; Clark et al. 2009). The increase in the rate of sea-level rise - Meltwater Pulse (MWP) 1A (Fairbanks 1989) — correlates roughly with warming of the North Atlantic region during the Bølling warm period $\sim 14.6 \mathrm{ka} \mathrm{BP}$ (Fig. 2.6 (b)). During MWP$1 \mathrm{~A}$, with values of about $2.8 \mathrm{~cm} /$ year, the rate of sea-level rise reached its maximum of the last deglaciation. During the Younger Dryas stadial, cold climatic conditions and droughts returned for a relatively brief period, also referred to as the 'Big Freeze', between $12.9 \mathrm{ka} \mathrm{BP}$ and $11.7 \mathrm{ka}$ BP, influenced obviously by the collapse of the North American ice sheets. The Younger Dryas cooling stadial is reflected by a deceleration of sea-level rise before another acceleration starting around $11.7 \mathrm{ka}$ BP together with the Holocene warming. During the Holocene, the climate fluctuated between positive and negative temperature and precipitation anomalies. Based on IRD investigation of North Atlantic sediments, Bond et al. (1997; 2001) claim the appearance of a quasi-periodic cycle of cold events during the Holocene with a period of $1470 \pm 500$ years, similar to the period of D-O events. These Bond-Cycles, numbered from 0 to 9 , are believed to be the result of insolation being driven southward, and eastward advection of cold, ice-bearing surface waters from the Nordic and Labrador seas, but discussions about a theory for the cause of Bond-Cycles are still ongoing. In order to gain a deeper understanding of these climate fluctuations, Wanner et al. (2011) analyzed a global set of Holocene time series from paleoclimate onshore proxy data. The authors identified six specific cold events (8200, 6300, 4700, 2700, 1550 and $550 \mathrm{BP}$ ). These events are plotted in Fig. 2.7 together with Bond events 0 to 6 . Looking for the reasons of the cooling events, Wanner et al. (2011) mention a complex system of driving forces including meltwater flux into the North Atlantic, low solar activity, explosive volcanic eruptions, fluctuations of the thermohaline circulation, and internal dynamics in the North Atlantic and Pacific area. 


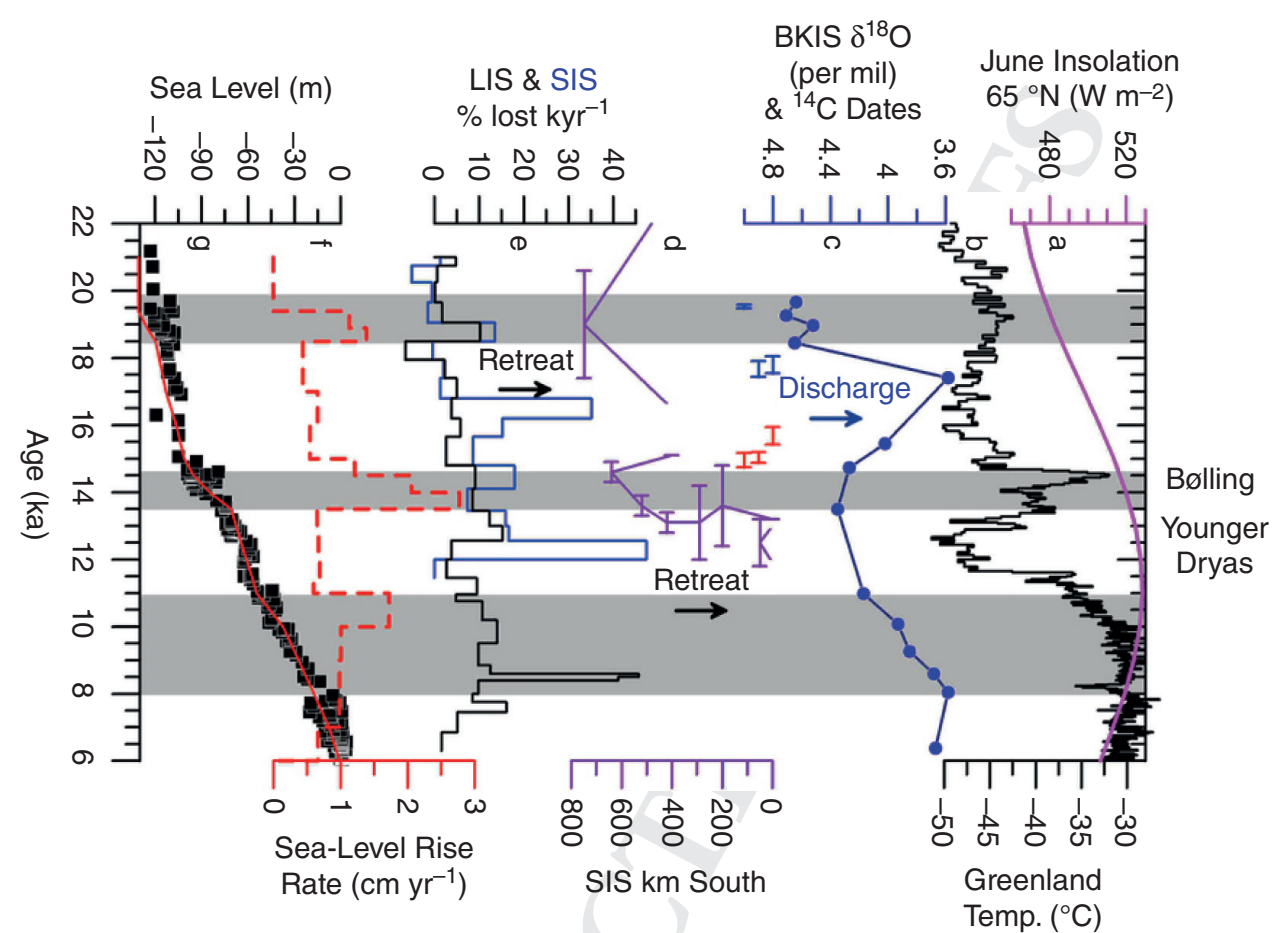

Fig. 2.6 Records of Northern Hemisphere ice sheets during the last deglaciation after Carlson (2011). (a) June insolation at $65^{\circ} \mathrm{N}$ (Berger \& Loutre 1991); (b) Greenland temperature based on ice-core oxygen isotopes ( $\delta^{18} \mathrm{O}$ ) converted to temperature (Cuffey et al. 1995); (c) A record of the Barents-Kara ice sheet (BKIS) discharge based on planktonic $\delta^{18} \mathrm{O}$ (Jones \& Keigwin 1988). Lower isotope values indicate more ice-sheet discharge from retreat $\sim 18 \mathrm{ka}$ (note the lighter isotopes after $\sim 12$ ka reflect warming, not ice-sheet retreat). Also shown are radiocarbon $\left({ }^{14} \mathrm{C}\right)$ dates that indicate BKIS retreat starting 20 ka to $18 \mathrm{ka}$ (blue bars) and when the ice sheet was essentially gone 16 ka to $15 \mathrm{ka}$ (red bars) (Landvik et al. 1998); (d) Distance south of the southern Scandinavian ice sheet (SIS) relative to its extent $\sim 12 \mathrm{ka}$ as determined by cosmogenic isotope dates on glacial boulders (Rinterknecht et al. 2006). The bars indicate the uncertainty in the timing of each ice position; (e) Rate of Laurentian ice sheet (LIS) (black) and Cordilleran ice sheet (CIS) (blue) retreat based on the percent of their area lost per kyr reconstructed by ${ }^{14} \mathrm{C}$ dates (Dyke 2004). Note that the abrupt increase in CIS retreat $\sim 12.5 \mathrm{ka}$ is an artefact of rapid thinning up to $\sim 13$ ka that exposed the underlying mountains and greatly reduced the area of the CIS; (f) Rate of sea-level rise (Clark et al. 2009); (g) Sea level from individual estimates (black squares) and a sea-level model (red line) (Clark et al. 2009). Gray bars show periods of rapid sea-level rise (see discussion in text, pages $[x * x][x \times x])_{-2}$ The Bølling and Younger Dryas are also indicated.

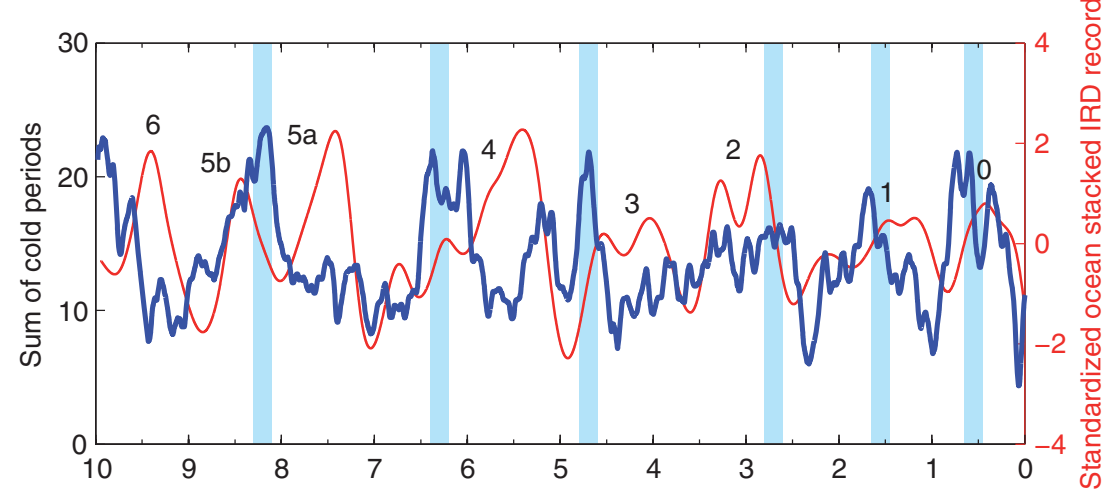

Fig. 2.7 Weighted and smoothed curve representing the sum of cold periods (x-axis: time in ka BP). Red curves with the numbers in each figure show the standardized ocean-stacked ice-rafted debris (IRD) record representing the Bond events no. 0-6 (Bond et al. 2001). The six vertical blue bars denote the time of the cold events after Wanner et al. (2011: fig. 8). 
The influence of climatic fluctuation on eustatic sealevel during the Holocene is a matter of debate and depends on the resolution of sea-level reconstructions. It is generally accepted that Holocene warming caused a continuous slow sea-level rise. The final stages of deglaciation during the Early Holocene caused an increase in the mass of water in the sea, while the slower sea-level rise after ca. $6000 \mathrm{BP}$ is predominantly the result of thermal expansion of the marine water mass. On the regional to local scale, the sea level has to be regarded as the relative change of the water level as a result of the interaction of eustatic changes and glacio-isostatic adjustment (GIA). A special phenomenon is the formation of dammed meltwater reservoirs in front of the retreating ice sheets. The water level of these basins may rise rapidly, but may also fall dramatically because of sudden drainages. This phenomenon together with the effects of glacioisostatic and hydro-isostatic effects will be discussed in the following sections.

\section{The Quaternary and European Sedimentary Environments}

The landscape of northern Europe was generally shaped by the Quaternary glaciations. Glaciers carved the Earth's surface, and enormous masses of glacial, glacio-fluvial, eolian, and also organic sediments were transported and deposited during the Quaternary. Most of the recent drainage system of Europe can be traced back to glacial or interglacial periods. Figure 2.8a shows the extent of the four European ice sheets (Weichselian Glaciation, Warthe phase of the Saalian Glaciation, Saalian Glaciation, and Elsterian Glaciation.

The change between glacial and interglacial periods led to a change of load on the continents caused by the build-up and decay of ice masses, resulting in local depression and rebound of the Earth's crust, whilst the global sea level dropped and rose according to changes in water volume. After the LGM, these processes caused 'drowned' fjord coastlines and uplifted beaches along the northern European coasts (the degree of drowning or uplift related to GIA effects), and the formation of the Irish Sea, the present North Sea, the English Channel, and the tilting of the Baltic Sea basin. During the ice advances from the north-east, the European drainage system - directed originally to the North Sea basin — was reorganized. Ice, wind and fluvial transport caused a general southward-directed redistribution of fluvial, glacial and eolian sediments. This process of re-organization of sediment distribution changed cyclically with the alternations from glacial to interglacial environment and vice-versa.

Four broad environmental domains, characterized by their depositional histories, can be distinguished in Europe according to Plant et al. (2003) in Fig. 2.8b. The source region for glacial sediments - the Fennoscandian region - underwent a net loss of material by glacial scouring. The environment is determined here by crystalline bedrocks, glacial psammites and tills, Ushaped valleys, fjords and lakes. Much of northwest and central Europe, south to $50^{\circ} \mathrm{N}$, is to be regarded as a glacial sink of sediments consisting of glacial tills, glaciofluvial and eolian sediments. South of $50^{\circ} \mathrm{N}$, fluvial sediments and loess rest on an older pre-Quaternary basement. Regionally, the Alpide orogenic belt (Alps and Pyrenees), hosted glacial ice sheets and interrupted the general European pattern of the Quaternary sedimentary environment. Fluvial and mass movement sediments prevail in the Mediterranean area.

\section{Glacio-isostatic Adjustment and Relative Sea-level Modeling}

The solid Earth deforms under the influence of changing loads on its surface. These deformations occur on different timescales and originate from different regions of the Earth's interior. The timescales vary from instantaneous to response times of several thousand years, depending on the period for which the load was acting on the Earth. Instantaneous, elastic reactions are conducted by the lithosphere as well as the Earth's mantle. Time-dependent viscous reactions originate solely from 
the mantle and correspond to the redistribution of viscous mantle material beneath the load. Hence, as a good approximation, the viscoelastic solid Earth can be modeled as a Maxwell body, which is the combination in series of an elastic (Hooke) model and a viscous (Newton) model. The former can be represented by a spring while the latter can be illustrated by a dashpot.

Surface loads vary on a wide range of timescales. For example, tidally-induced redistributions of ocean water or changing atmospheric loads vary with frequencies of hours to several days and will only induce elastic deformations in the earth. In contrast, long-term changes of surface loads, such as during the waxing or waning of ice sheets, will induce both elastic and viscous deformation. These deformations are isostatic and will continue until the Earth has returned to a state of equilibrium. If the Earth's response is induced by glacial load changes it is referred to as glacio-isostatic adjustment (GIA).

The deglaciation of an ice sheet invokes a more complex response of the Earth than a purely viscoelastic deformation, however. In addition, on a global scale,

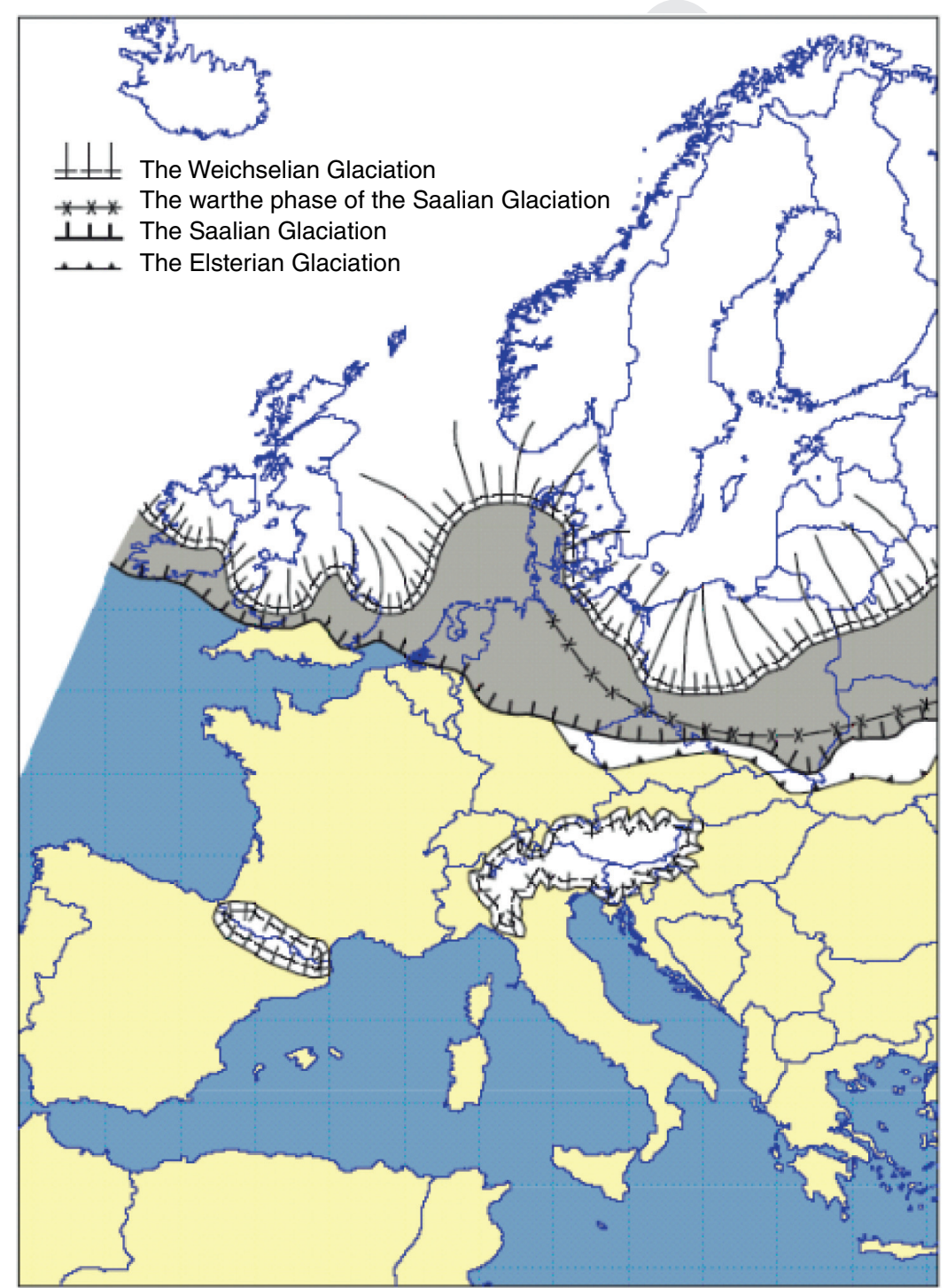

Fig. 2.8 Scandinavian ice-sheet dynamics with special respect to the Weichselian Glaciation Regional Quaternary depositional environments of Europe: (a) Maximum extent of the European ice sheets: the Weichselian Glaciation, the Warthe phase of the Saalian Glaciation, the Saalian Glaciation, and the Elsterian Glaciation (from Anderson \& Borns 1997); (b) Depositional environments: Zone A - Pre-Quaternary bedrock, rock-, sand- and gravel-based tills, hummocky topography, U-shaped valleys, fjords and lakes; Zone B - complex of interbedded loessic eolian sands, soils, tills, and fluvial glacial sediments; Zone C periglacial zone with fluvial glacial outwash sediments, loess and periglacial weathering; Zone D - fluvial and mass-movement deposits; gray shaded areas $=$ upland glaciations. After Plant et al. (2003: fig. 2). 
Fig. 2.8 (Continued)

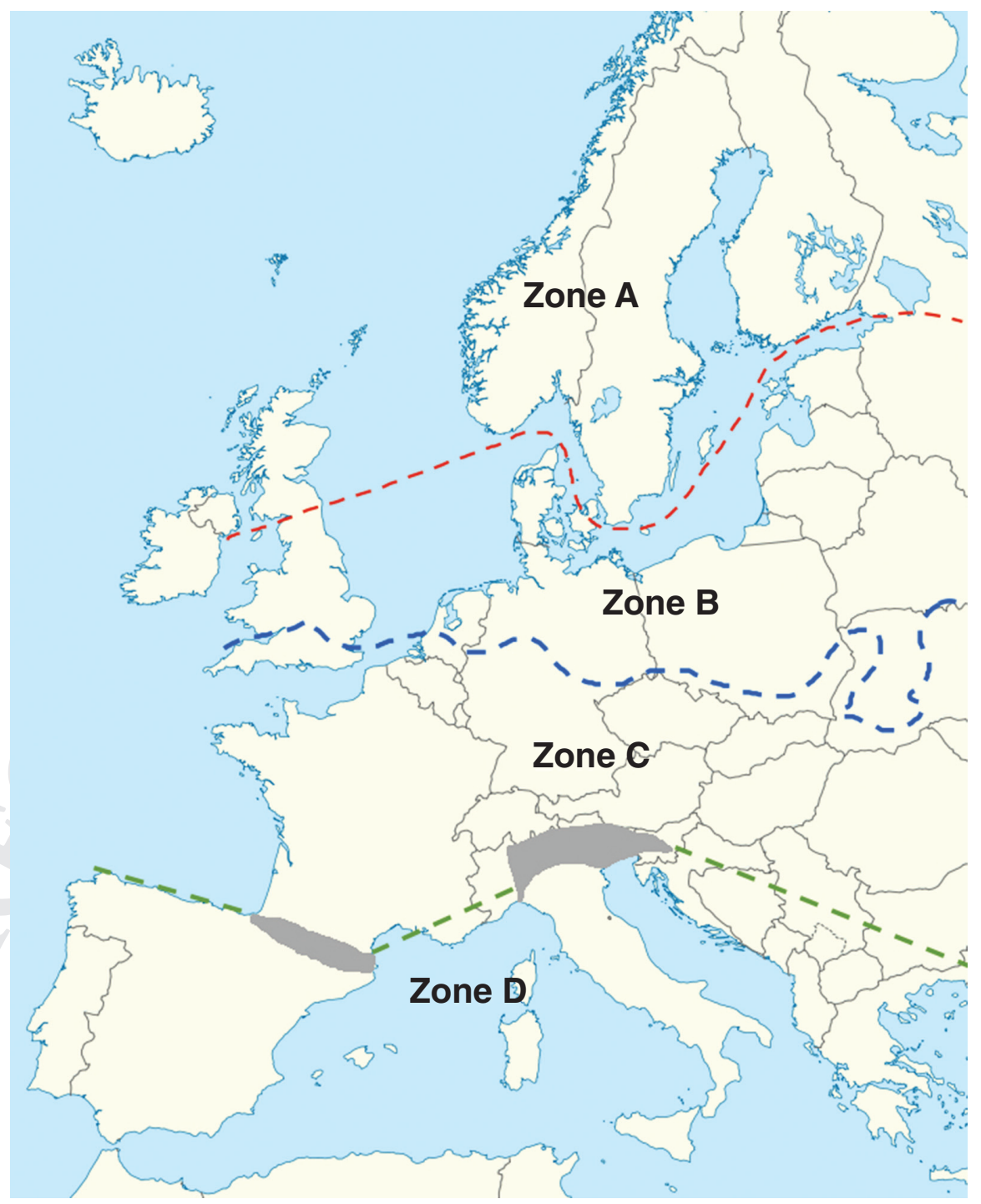

average sea level will rise due to the meltwater influx (eustatic sea-level change). But the mean sea surface is an equipotential surface of the Earth's gravity field. Hence, changes in the Earth's gravity potential due to the decreasing ice mass and the redistributed mantle material will cause a highly non-uniform change in sea level. Moreover, the relocated water mass is another surface load which induces additional crustal deformation and an additional deformation potential. A gravitationally selfconsistent description of these interactions is given by the sea-level equation (SLE). The basic idea of the SLE dates back to the work of Woodward (1888), while the SLE was formulated by Farrell and Clark (1976). According to
Peltier (1998) (see also Groh et al. (2011)) the SLE reads as:

$$
\begin{aligned}
\delta \mathrm{S}(\theta, \lambda, \mathrm{t})= & \mathrm{C}(\theta, \lambda, \mathrm{t}) \cdot\{\delta \mathrm{G}(\theta, \lambda, \mathrm{t})-\delta \mathrm{R}(\theta, \lambda, \mathrm{t})\} \\
= & \mathrm{C}(\theta, \lambda, \mathrm{t}) \cdot\left\{\int \left[\int \int \left(\mathrm{g}^{-1} \Phi\left(\psi, t-t^{\prime}\right)\right.\right.\right. \\
& \left.\left.-\Gamma\left(\psi, t-t^{\prime}\right)\right) \cdot \mathrm{L}\left(\theta^{\prime}, \lambda^{\prime}, t^{\prime}\right) d \sigma\right] d t^{\prime} \\
& \left.+\mathrm{g}^{-1} \Delta \Phi(\mathrm{t})\right\}
\end{aligned}
$$

At a given position (co-latitude: $\theta$, longitude: $\lambda$ ) and time $(\mathrm{t})$ the change in RSL $(\delta \delta S)$, which is the 
sea level relative to the Earth's crust, is the difference between the change of the geoid $(\delta \mathrm{G})$ and the vertical crustal deformation $(\delta R)$. The geoid is a surface of constant gravitational potential and corresponds to the mean sea level. $\mathrm{C}(\theta, \lambda, t)$ is the so-called ocean function which is unity over the ocean and zero over land. In general, $\mathrm{C}$ is time-dependent as well since land areas can subside below sea level or ocean regions can be uplifted above sea level while an ice sheet melts or aggregates. In more detail, the SLE reveals that $\delta \mathrm{G}$ and $\delta \mathrm{R}$ result from the temporal and spatial convolution of the Green functions for the gravitational potential $\Phi$ and for the vertical deformation $\Gamma$ with the load $L$. The conservation of the total mass of ice and water is assured by the purely time-dependent term $\mathrm{g}^{-1} \delta \Phi(\mathrm{t})$ where $\mathrm{g}$ is the gravitational acceleration. The Green functions depend on the spherical distance $\psi$ between the position under consideration $(\theta, \lambda)$ and the load element $\left(\theta^{\prime}, \lambda^{\prime}\right)$ as well as on the viscoelastic properties of the Earth. The load distribution $\mathrm{L}$ incorporates load changes of the ice and of the changing sea level $\delta S$ itself. Hence, this linear integral equation has to be solved iteratively. In this basic form the SLE does not account for effects induced by changes in the rotational feedback of the Earth.

Thus, modeling of GIA-induced phenomena, such as present-day RSL changes or the temporal evolution of RSL, by solving the SLE, requires several different input data sets. First, an ice-load history describing the temporal and spatial evolution of the ice load is needed. Second, a viscoelastic Earth model is required to solve for the Green functions. Ice-load histories are available on global and regional scales and are reconstructed from geological, geomorphological and archaeological evidence of the former ice extent and of the past sea level. A few models incorporate dynamic ice models, too. Usually the Earth model is jointly inferred with the ice-load history (Lambeck et al. 1998a). Instrumental records of present-day RSL changes from tide gauges or of present-day crustal deformations from global positioning systems (GPS) are often used to constrain or validate the inferred ice-load histories and Earth models (e.g. Lambeck et al. 1998b; Milne et al. 2001). One widelyused global ice-load history is ICE-5G (Peltier 2004). The corresponding viscoelastic Earth model VM2 was chosen in a way that best fits the utilized observational data set in a global sense. Another global model was developed by Kurt Lambeck. The Fennoscandian component of this model is described by Lambeck et al. (1998a). In contrast to VM2 the corresponding Earth model is particularly constrained to the Fennoscandian dataset. Hence, this Earth model cannot be used within global studies but is most appropriate for studies in Fennoscandia. Both models provide an ice-load history from the LGM period until the present. The results are well constrained by the rich observational data set for this period. A global model of sea level and ice volumes based on observations distant from the ice sheets has been published by Lambeck et al. (2014).

Figure 2.9 shows the present-day GIA-induced vertical crustal deformations over Europe. The underlying calculations are based on the ice-load history ICE-5G and the corresponding Earth model VM2. The utilized software (Spada \& Stocchi 2007) solves the SLE for a radially stratified, incompressible, non-rotating Earth in the spectral domain and does not account for a timedependent ocean function. A generalized version of the VM2 model, consisting of an elastic lithosphere $(120 \mathrm{~km}$ thickness) and three viscous mantle layers (viscosities: upper mantle: $0.5 * 10^{21} \mathrm{~Pa} * \mathrm{~s}$; transition zone: $0.5 * 10^{21}$ $\mathrm{Pa} *$ s; lower mantle: $\left.2.0 * 10^{21} \mathrm{~Pa} * \mathrm{~s}\right)$ was used. The iceload history is given in $1 \mathrm{kyr}$ steps and predicts a global eustatic sea-level rise of about $127 \mathrm{~m}$ since the LGM at $21 \mathrm{ka}$ BP. The deformation pattern reveals a large uplift dome at the former center of glaciation around the Gulf of Bothnia with a maximum rate of uplift of more than 9 $\mathrm{mm} /$ year. This uplifting region is surrounded by a zone of slight subsidence. This zone corresponds to the collapsing peripheral bulge from where the mantle material is still being redistributed back to central Fennoscandia. As in all former glaciated regions, the crustal deformations are the dominating signal and GIA-induced changes of the geoid are relatively small. In Fennoscandia they do not exceed the $0.5 \mathrm{~mm} /$ year level. Hence, the present-day fall in RSL due to GIA reaches a maximum of about $8 \mathrm{~mm} /$ year. Over ocean regions further away from the former ice sheet the dominating part of the present-day crustal deformation originates from the additional water 
Fig. 2.9 Present-day vertical crustal deformation rates caused by changing ice and ocean water loads since LGM according to ICE-5G (VM2). A. Groh with data from Peltier (2004).

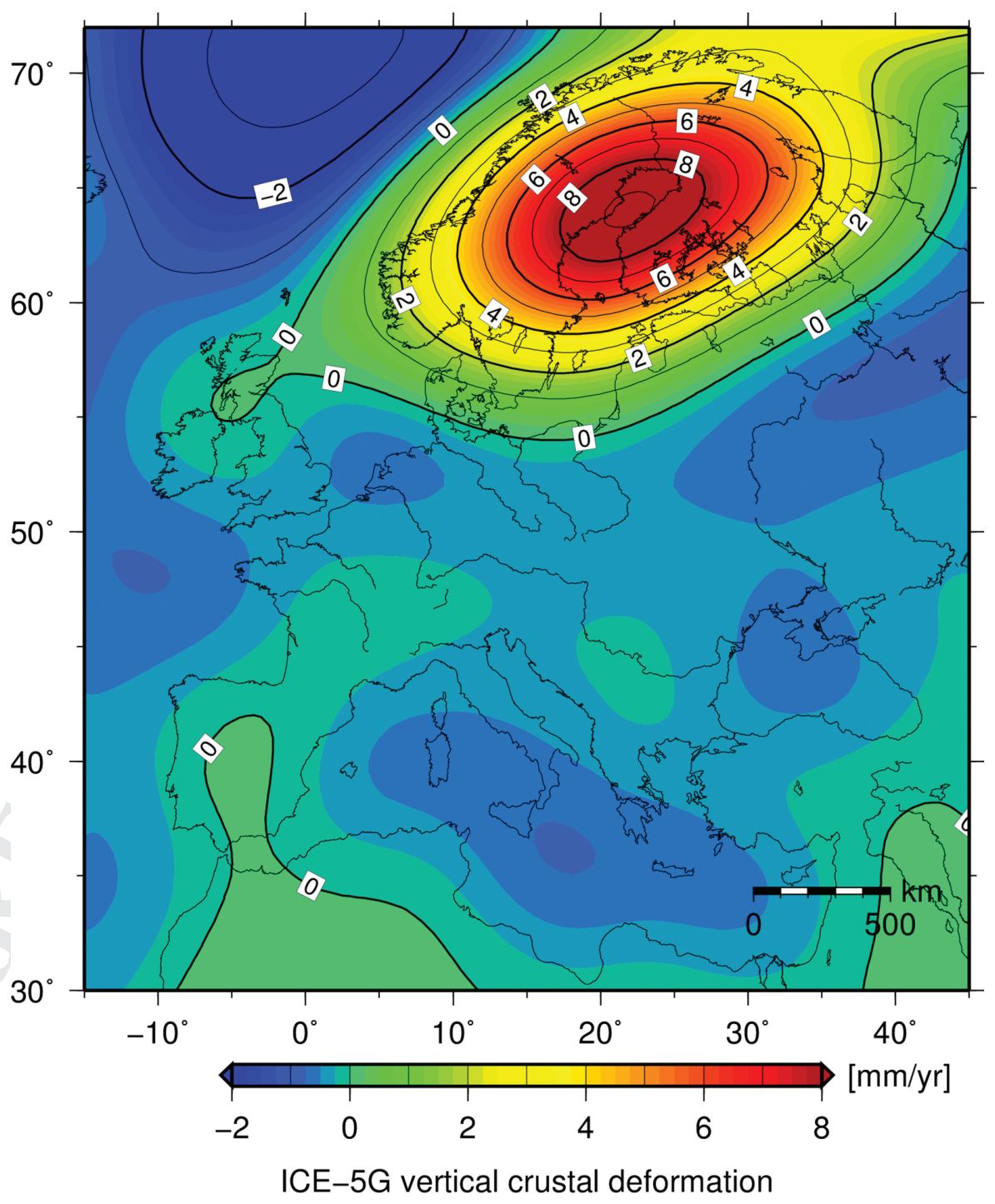

\section{The Baltic Glacio-isostatic Adjustments}

The expansion and contraction of the Fennoscandian ice sheet is relatively well recorded by geological proxies as are also the effects of relative sea-level changes. Therefore, models described in the preceding sections have been applied to the Baltic area for several years in order to describe the effect of deglaciation to the region (Harff et al. 2007; 2011; Lambeck et al. 2010). But, for earlier periods of the glacial cycle the observational evidence can be poor. Nevertheless, Lambeck et al. (2010) have used chapters. 

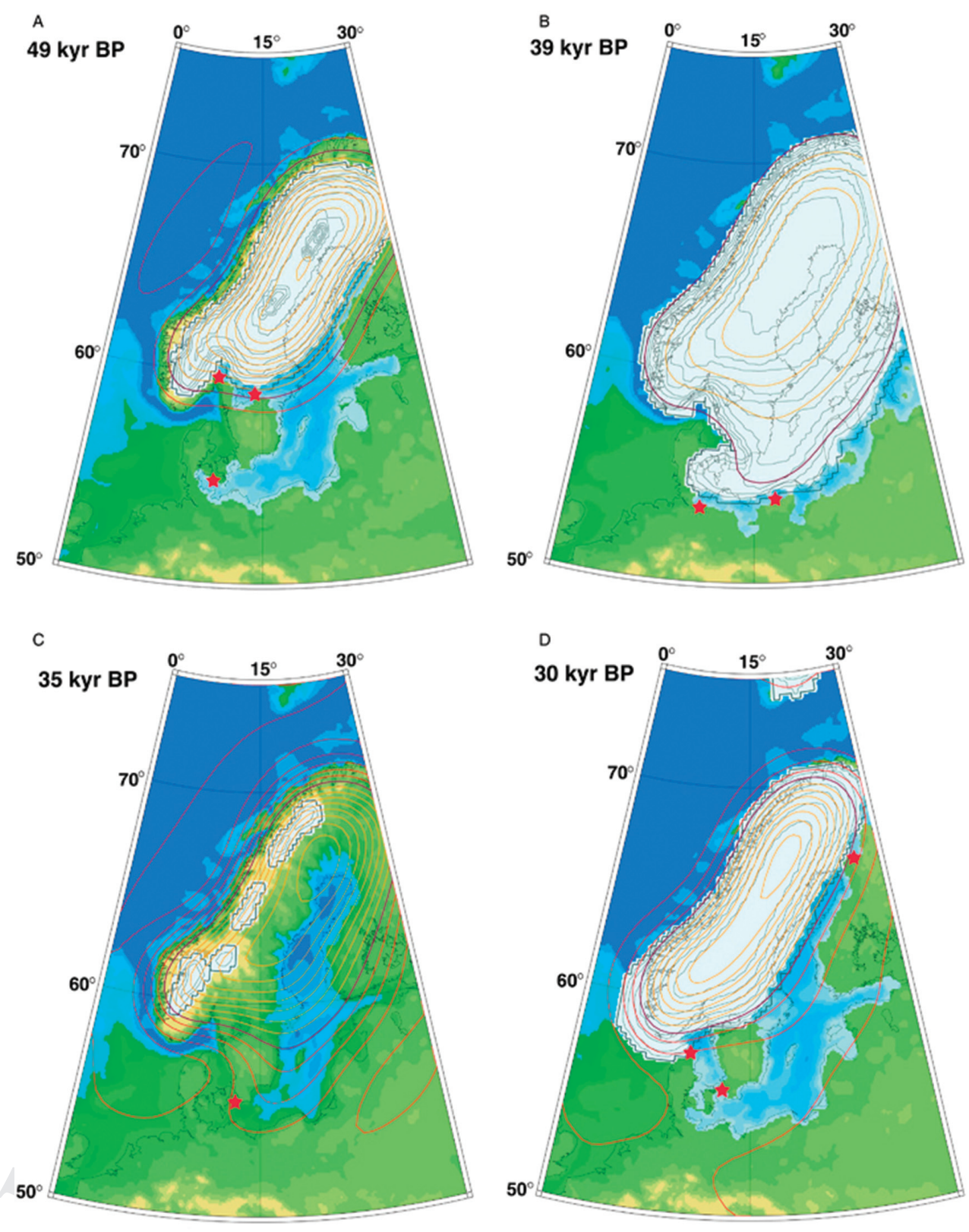

Fig. 2.10 Paleogeographical reconstructions for three principle interstadials and stadials during MIS 3. Ice-thickness contours: $200 \mathrm{~m}$. Positive relative sea-level contours (orange), negative ones (red). Red stars mark thresholds of ice-marginal lakes. Lambeck et al. (2010).

their inversion method (Lambeck et al. 1998a) and the rich data set for LGM and post-LGM periods to constrain the behavior of the ice sheet (Fig. 2.10). These constraints, the sparse observational evidence and assumptions on the prevailing basal conditions are further used to extrapolate back to earlier times, resulting in an ice-load history for the preceding MIS 3 ( 60-30 ka BP).
After the Weichselian ice sheet had covered the whole Baltic basin during the LGM, the ice retreated and melt water filled the basin at a time when the North Atlantic was still covered by sea ice. This first phase in the postglacial history of the Baltic basin named the Baltic Ice Lake (BIL) lasted from $16 \mathrm{ka}$ BP to $11.7 \mathrm{ka}$ $\mathrm{BP}$. The retreating ice enabled a connection between the 
Baltic basin and the Skagerrak area along the Central Swedish Depression for a short phase (the Yoldia Sea 11.7-10.7 ka BP) before the GIA uplift disconnected the Baltic basin again from the Global Ocean and another freshwater phase (Ancylus Lake) began at $10.7 \mathrm{ka}$ BP lasting until $8 \mathrm{ka}$ BP. The environment changed completely at about $8 \mathrm{ka}$ BP when, due to the collapsing lithospheric bulge in the southern Baltic area and continuous eustatic sea-level rise, marine water masses transgressed through the Kattegatt into the Baltic basin (Littorina transgression) converting the former freshwater reservoir to a permanent brackish-marine environment (Andrén 2011, Harff et al. 2011). During the Atlantic (2.5-0 ka BP) and the Subatlantic (8-5 ka BP) periods, coastline development in the Baltic basin was the result of a complex interaction between eustatic sea-level rise and GIA. In the south, subsiding land and eustatic sea-level rise caused a permanently retreating coast. In the north, eustatic rise was overcompensated by GIA uplift, resulting in continuous regression of the sea (Fig. 2.11).
The water (sea) level history reconstructed for the Narva-Luga basin in the eastern Gulf of Finland impressively demonstrates the interplay between isostatic uplift and eustatic water-level change (Rosentau et al. (2013; Fig. 2.12). After the Baltic Ice Lake stage and a $25 \mathrm{~m}$ drop in water level by drainage of the ice-dammed lake, marine waters entered into the basin via the Central Swedish Depression for the duration of the Yoldia Sea period.

With the onset of the Ancylus Lake period, connection to the Global Ocean was closed off, and the water level rose permanently (Ancylus transgression) because of the inflow of melt water from the Fennoscandian ice sheet. By $9.8 \mathrm{ka}$ BP the Ancylus Lake began to drain and the water level dropped by more than $10 \mathrm{~m}$ (Ancylus regression). After $8.5 \mathrm{ka}$ BP the curve describes a eustatically controlled sea-level rise because of an open connection of the Baltic basin to the marine realm of the North Sea area. The end of the transgression is marked by a well-developed raised beach around $7.3 \mathrm{ka}$ BP. The following sea-level drop in the curve of Fig. 2.11 is caused by the GIA-uplift of the Fennoscandian Shield which
Fig. 2.11 Areas of transgression (blue) and regression (red) of the Baltic Sea since the Littorina transgression ca. $8 \mathrm{ka}$ BP, modified from Harff et al. (2007). Narva-Luga area (Fig. 2.12) and Darss-Zingst Peninsula (Fig. 2.20) are marked.

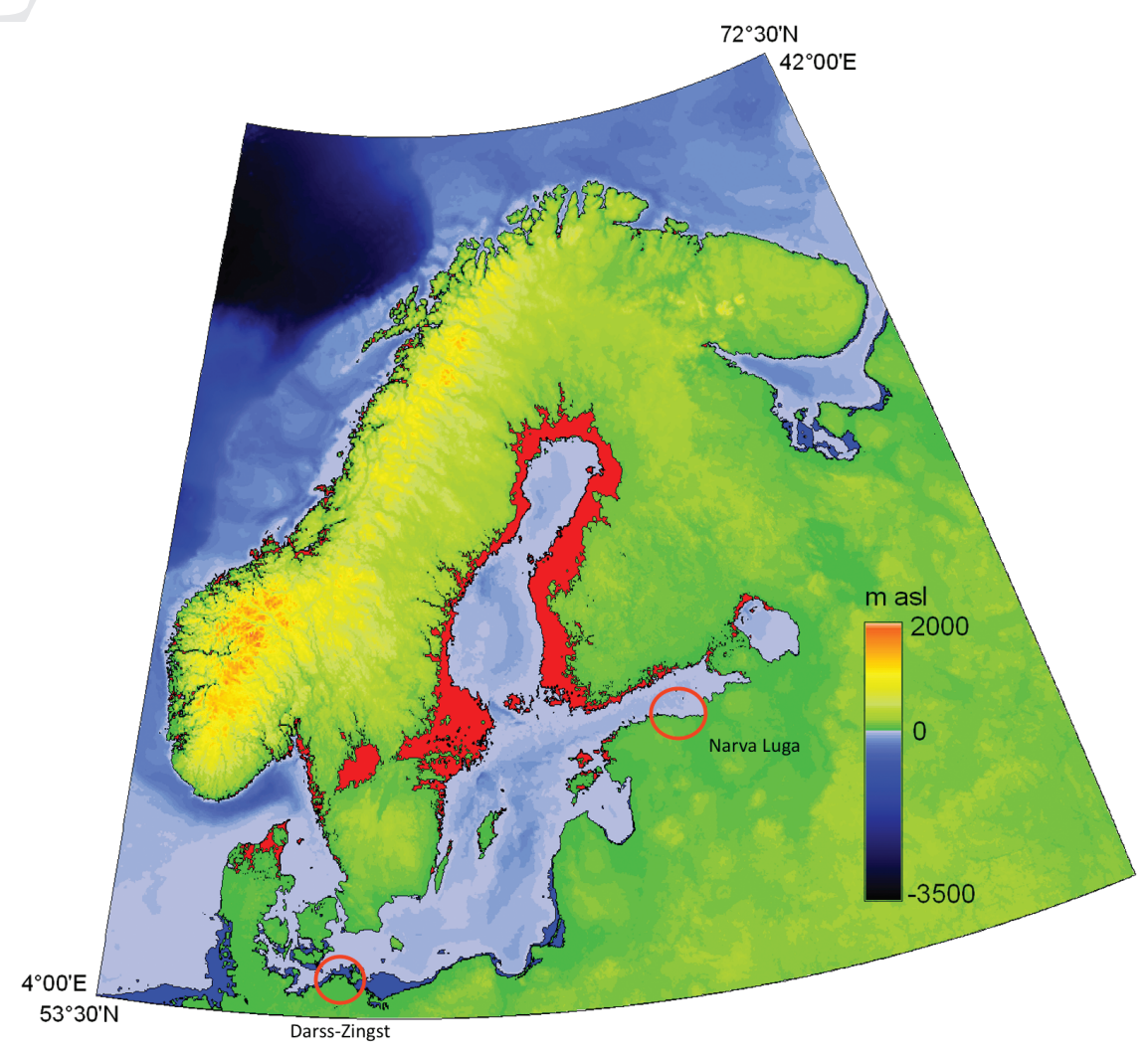




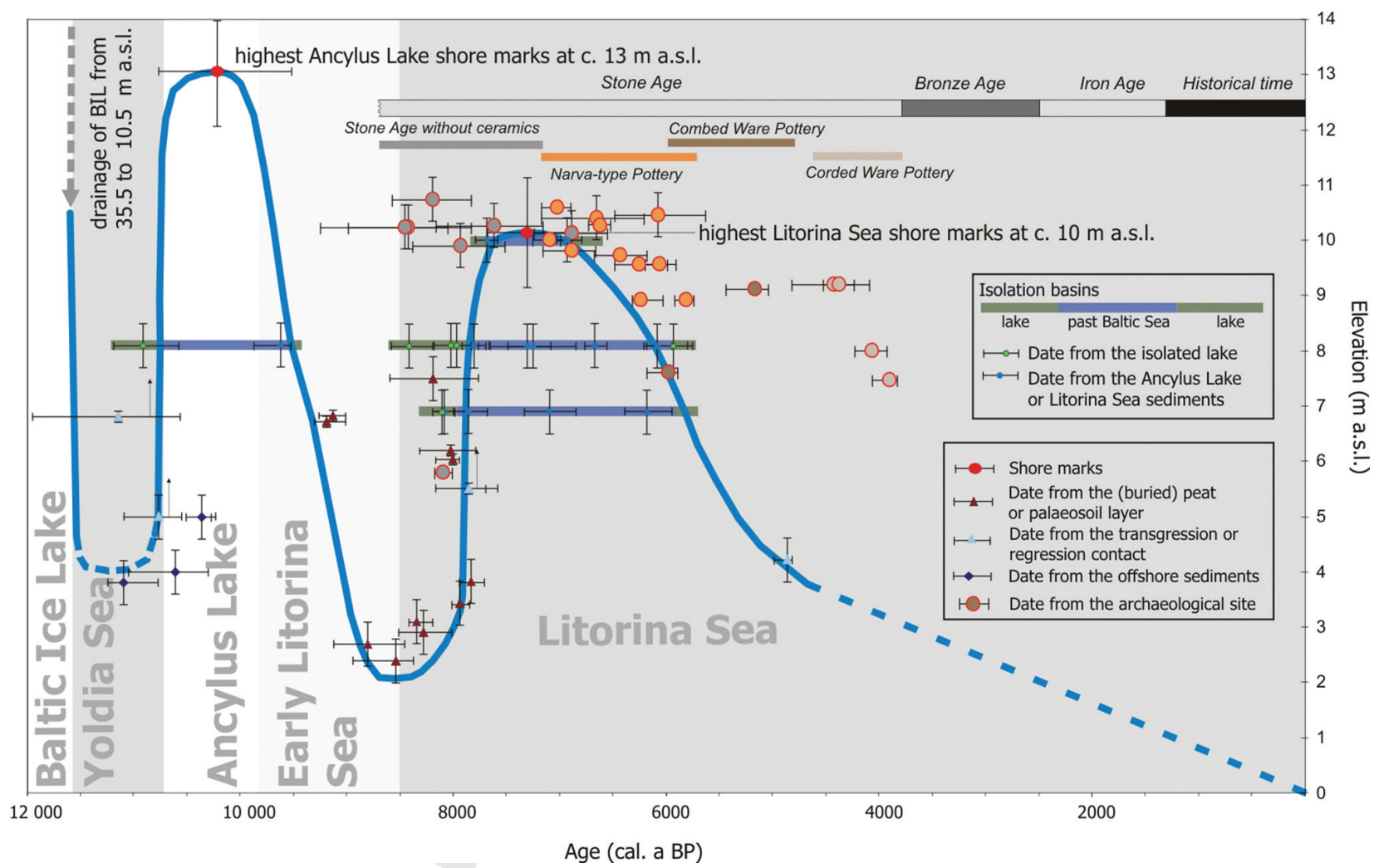

Fig. 2.12 Relative water-level change curve for Narva-Luga area (location marked in Fig. 2.11) in the eastern Gulf of Finland. Modified from Rosentau et al. (2013).

started to outpace eustatic sea-level rise in the Narva-Luga area.

\section{North Sea and Atlantic Shelf from the Last Glacial Maximum to the Atlantic Period}

Model results have been produced based on the inversion of sea-level data from the British Isles and northern Europe, complemented with inversions of data from North America and from areas far from the former ice sheets (Peltier et al. 2002; Milne et al. 2006; Shennan et al. 2006; Hanebuth et al. 2011). The shoreline reconstructions are thus predictions based on these solutions without taking into account the effect of local tectonics, erosion and sedimentation. Normally, these results are compared with independent observational evidence of paleoshorelines not used in the solutions; if there are major discrepancies, this additional information is used to improve upon the solution. These model results have not yet been compared with such additional data and are therefore a first iteration. Accordingly, we will consider the probable magnitude of the unquantified factors, and then consider the predicted results at different time intervals.

The North Sea and extended Northwest Shelf of Europe consist of a series of shallow semi-enclosed basins and marginal seas typically in the depth range of $50 \mathrm{~m}$ to $100 \mathrm{~m}$. They are profoundly influenced by Atlantic storms from the west, and tidal amplitudes are frequently of the order of $2 \mathrm{~m}$ to $5 \mathrm{~m}$, and over $10 \mathrm{~m}$ in some limited areas, with associated strong currents (Neill et al. 2009; 2010). The oceanographic conditions result in vigorous erosion and redistribution of coastal sediments. These include actively mobile sedimentary features such as sand 
waves, sand banks, and sand ribbons on the sea floor, as well as massive accumulations of sediments on the outer shelf of the western approaches in the Celtic Sea (Lericolais et al. 2003; Toucanne et al. 2009) brought down by the Channel River during glacial melting and deposited during sea-level rise. Gibbard (1988) provides a longer timescale for the analysis of the European rivers on the continental shelf. The calculated GIA movements and the present position of ancient shorelines and areas of drowned terrestrial landscape previously exposed at different dates could therefore be influenced by, or concealed by, local and regional tectonics, erosion, and extensive redeposition of postglacial marine sediments. In particular, they will not necessarily be detectable by bathymetric surveying alone, and will in many cases only be detectable by sub-bottom profiling or $3 \mathrm{D}$ seismic surveying (Bakker et al. 2012).

Tectonic activity on land and on the seabed in the British area of the Northwest Shelf, which is the largest proportion, has been a minor factor during the Quaternary (Barton \& Woods 1984; Thorne \& Watts 1989), although active graben formation and crustal extension and thinning of the central North Sea occurred during the Jurassic-Cretaceous. Crustal extension, rifting, and graben subsidence were at least partially counterbalanced by continuous infilling of the depressions by sediments. The Rhine graben does not continue into the North Sea. In contrast, the English Channel area has been subject to compression due to the Alpine orogeny (Lagarde et al. 2003). For the last 730,000 years the average subsidence of the central North Sea has been $0.4 \mathrm{~m} / \mathrm{kyr}$ (Cameron et al. 1992), amounting to $8 \mathrm{~m}$ in 20,000 years, while the uplift of the Channel region has been $0.1 \mathrm{~m} / \mathrm{kyr}$ (Lagarde et al. 2003), amounting to $2 \mathrm{~m}$ in 20,000 years. In both cases the tectonic factor is an order of magnitude smaller than the glacio-isostatic changes in the same period, and, at least in the case of the North Sea, subsidence as an effect on bathymetry may be offset by sediment accumulation.

Consistent with this observation, the recorded and current seismicity of the British Isles is very low, and furthermore a proportion of the recorded epicenters correlates with crustal adjustment arising from postglacial rebound (Musson 2007). The earthquake records in the
UK have been assessed by Musson (2007) and there have only been 35 events over Local Magnitude (LM) 4 since 1850, and none above LM 5.4 (Musson 2007, fig. 6).

Tsunamis are another factor which can change the bathymetric parameters and alter or conceal paleoshorelines. The Storegga event (Weninger et al. 2008) created waves which struck the coast of Scotland and the northern slopes of the Dogger Bank approximately $8.2 \mathrm{ka}$ BP. The major effect on seabed bathymetry was the additional mass of sediment in deep water off the Norwegian continental slope, and thus outside the interest of this study. No accurate calculation has been made of the quantitative effect on the submerged landscape in coastal waters, but Weninger et al. (2008, figs. 4 \& 5) show the areas most strongly impacted by the Storegga tsunami in the contemporaneous North Sea coastal waters, and on the northern flanks of the Dogger Bank.

When the relative velocities of vertical tectonics and glacio-isostatic earth movements compared with the vertical rate of rise of sea level produce a local relative stillstand, wave energy and currents produce cliffs, erosion, beach ridges, terraces, and active sediment transport. There should thus be identifiable submerged shorelines against which predicted GIA sea-level models can be verified or corrected. However, this is not a simple exercise since, in an area of extreme postglacial isostatic adjustment, the shore features occur at different depths and different times against the tilting land surface. This problem is addressed for the central North Sea by Ward et al. (2006). The complex task of identifying continuous shorelines in a terrain of very low relief during postglacial isostatic tilting is also facilitated by the detailed subsurface maps produced by Gaffney et al. (2007) and Bakker et al. (2012).

The models shown below have not been corrected for the factors mentioned above, and a complete comparison with paleoshorelines detected offshore has not been carried out. The first iteration results are therefore illustrated below. The impact of sea-level changes on human population movements into and out of the British Isles on a longer timescale is discussed extensively by Pettit and White (2012).

The results included and shown in Fig. 2.13 are for the following epochs: 

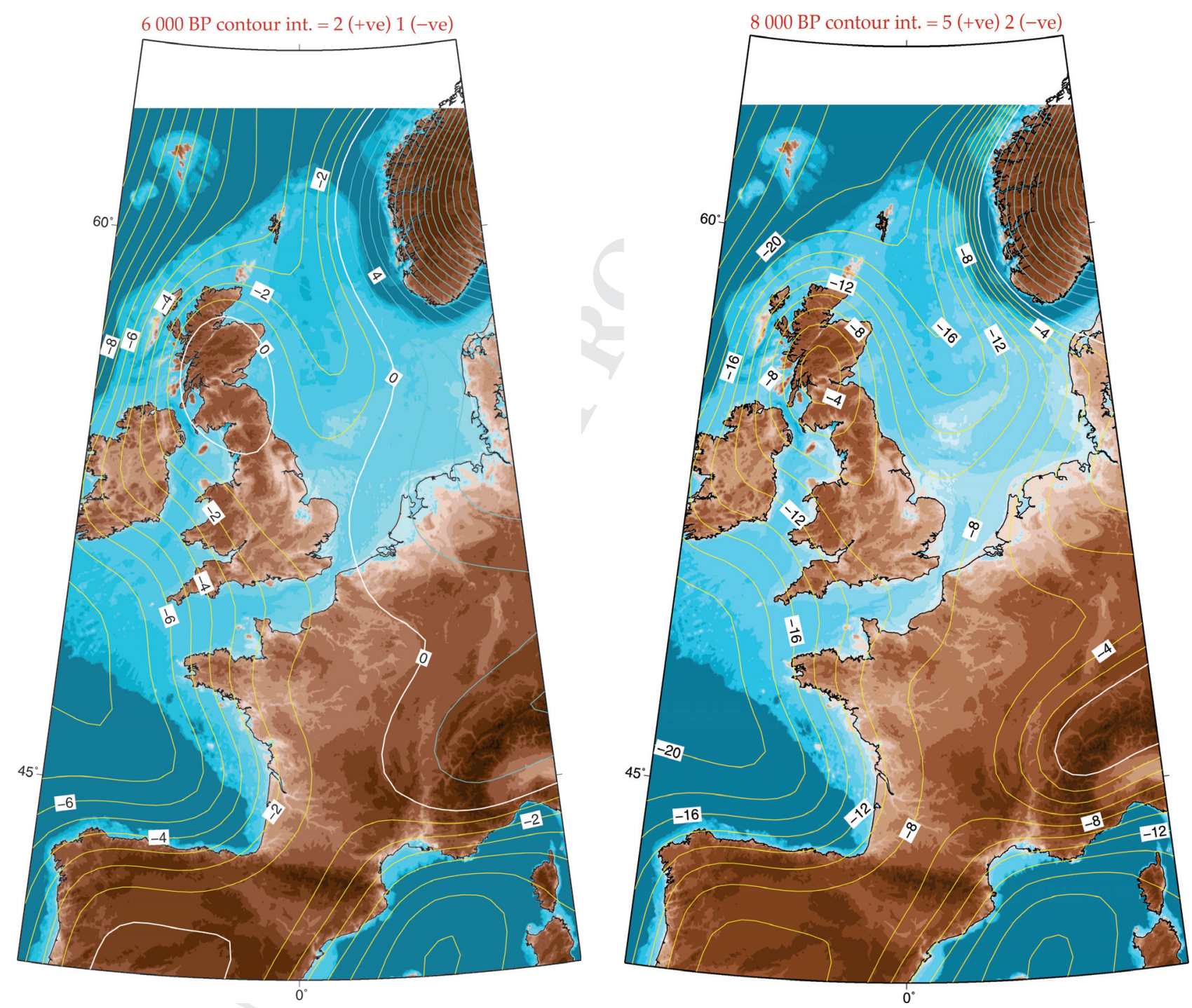

Fig. 2.13 Paleogeographic models of the North Sea and parts of the Northeast Atlantic shelf $20,16,12,10$, 8, and 6 ka BP. Based on Lambeck (1995), Lambeck and Purcell (2001), and Lambeck et al. (2010).

$1 \mathrm{~T}=20,000 \mathrm{BP}$ representing the late LGM interval. This is shortly after the maximum ice extent across the North Sea when retreat from the North Sea back to Norway and Scotland has already started. Northward retreat across England and the Irish Sea has also started before this time. ${ }^{\dagger}$
† In this chapter, in regards to model dates, a timescale of calendar years $\mathrm{BP}(=1950)$ is used, as model time is unrelated to any ${ }^{14} \mathrm{C}$ calibration
Ireland and England are tenuously connected via a very low land bridge across the southern Irish Sea across which flows the spillover from the ice-dammed lake to the north.

Much of the North Sea is exposed, including the locations east of Shetland where Late Glacial artifacts have been found on the present sea floor (Long et al. 1986).

$2 \mathrm{~T}=16,000$ BP representing the Late Glacial Period. The sea is beginning to advance across the North 

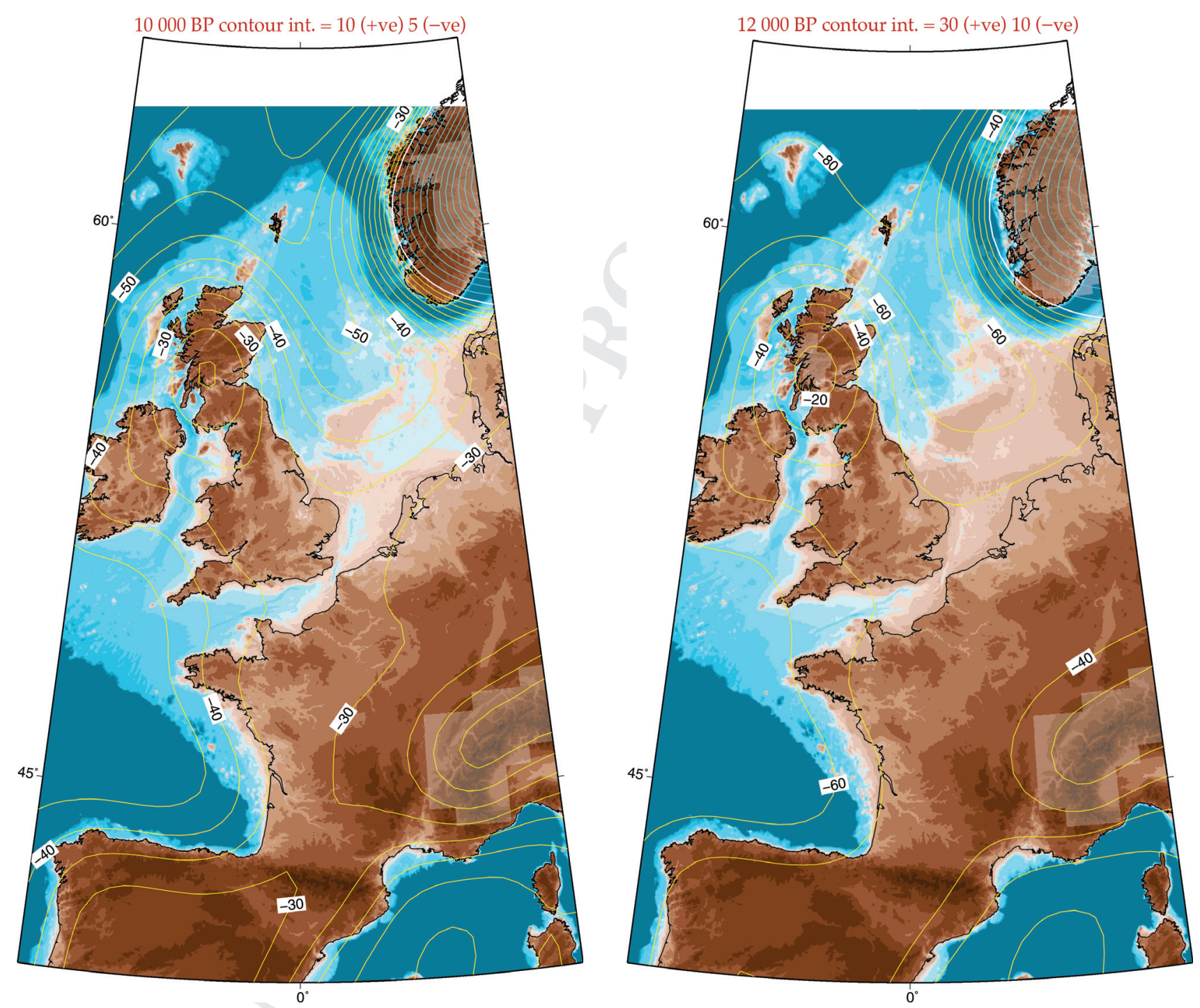

Fig. 2.13 (Continued)

Sea floor but quite slowly at first because the rebound is approximately keeping up with the rising water.

$3 \mathrm{~T}=10,000 \mathrm{BP}$, representing the separation of Dogger Bank and the early phase of the opening of the English Channel which is completed just before 9000 BP.

$4 \mathrm{~T}=6000$ BP. By 8000 years ago the shorelines have approximated their present locations but in the lowlying areas of the Netherlands, Belgium. Denmark and Germany sea level continues to rise and there is extensive inundation after about $7500 \mathrm{BP}$.

\section{Tectonic Controls: The Mediterranean Sea}

Paleogeographic models of the Mediterranean and Black Sea area have been presented by Lambeck and Purcell (2005; 2007) and Lambeck et al. (2011). But, for most of the areas along the Mediterranean coastline, sea-level models deviate from field observations and geological data. The reason for this discrepancy between models and observations is the ongoing geodynamic and tectonic 

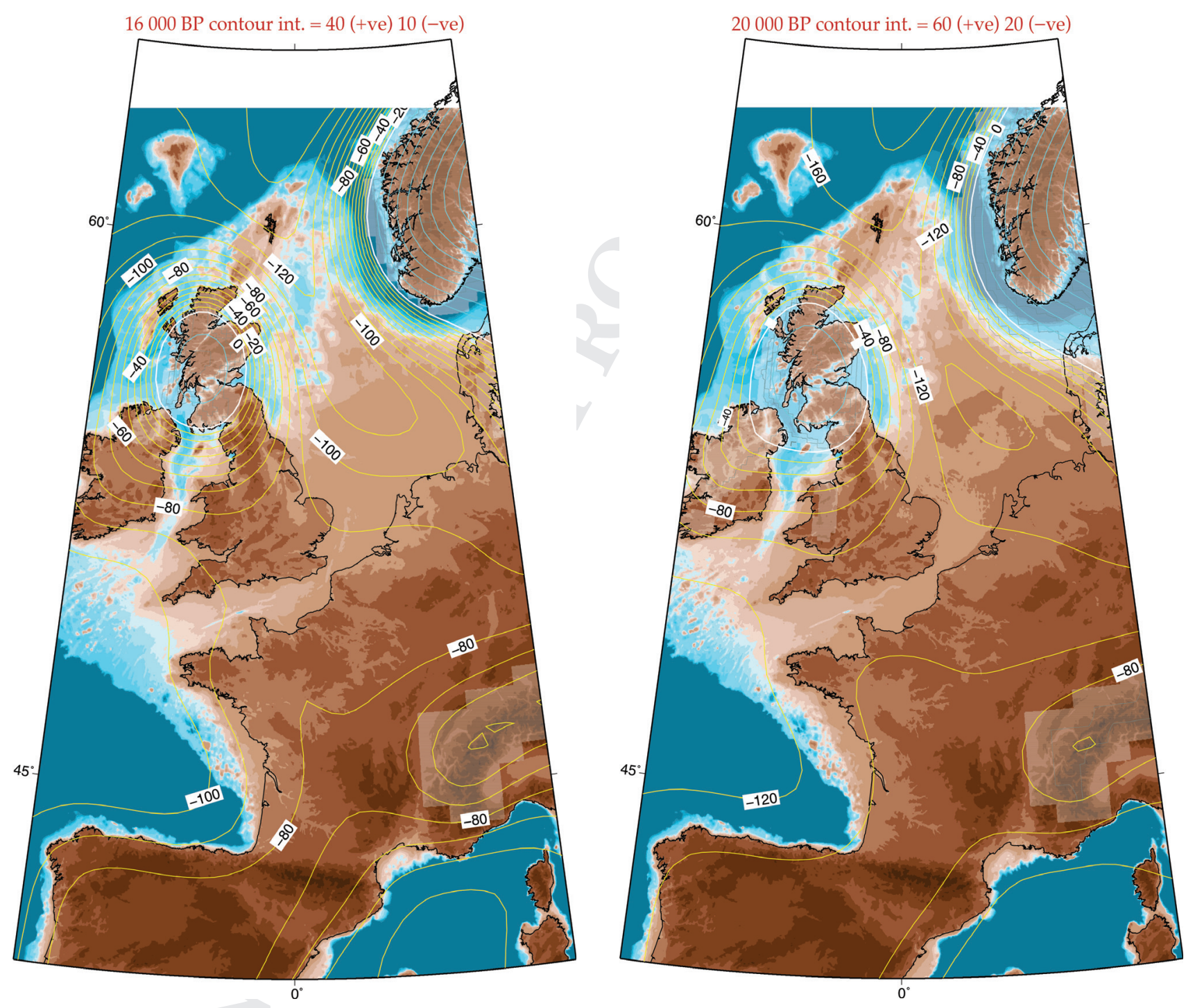

Fig. 2.13 (Continued)

processes and crustal deformation over most of the Mediterranean region. Active processes create a dynamic environment with long- and short-term, vertical and horizontal, crustal movements which are superimposed on and modify the effect of sea-level fluctuations. Comparison of observations and field data, including different geomorphological and archaeological sea-level markers, with the predicted sea-level curves provides estimates of the vertical tectonic contribution to relative sea-level change. Long-term vertical tectonic rates of movement can be inferred from the elevation of the $124 \mathrm{ka}$ last interglacial highstand (MIS 5.5) marker (Ferranti et al. 2006; Antonioli et al. 2009a, b). This marker, where developed and preserved, offers an excellent tool to estimate patterns of differential displacement within adjacent tectonic blocks (Lambeck et al. 2011).

Active tectonics in the Mediterranean and adjacent areas is predominantly driven by the convergence between the African and the Eurasian plates. Figure 2.14 shows the complex geotectonic structure developed due to the collision of these continental plates (compare also with the more general map of Fig. 2.2). Subduction of oceanic 


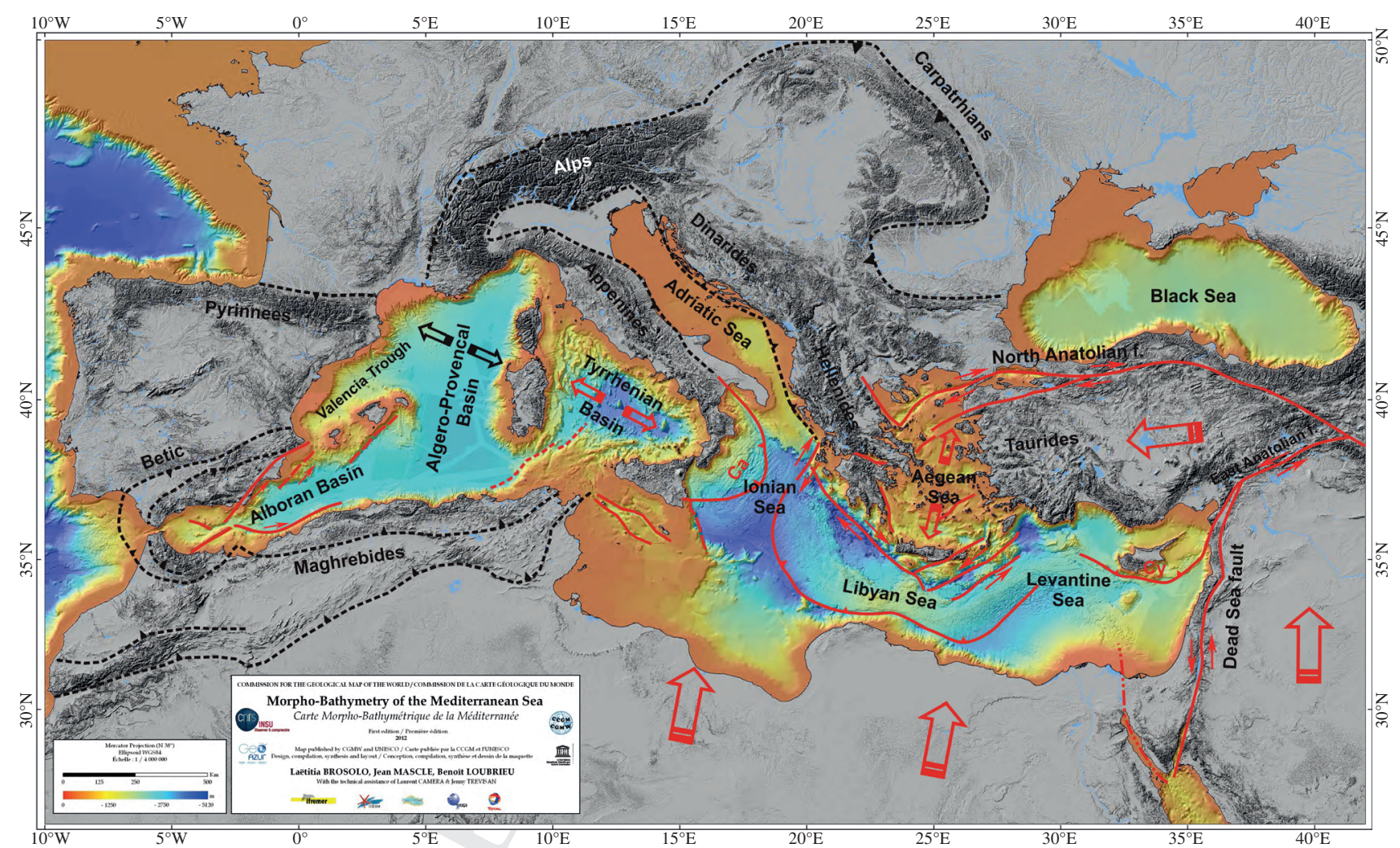

Fig. 2.14 Main geotectonic boundaries and features drawn on the Morpho-Bathymetry Map of the Mediterranean Sea (CGMW - Commission for the Geological Map of the World/UNESCO) Brossolo et al. (2012).

crust and/or collision of continental blocks goes on along the Betic-Rif orogenic belt, the Calabrian Arc, the Hellenic Arc and the Cyprus Arc. Active movements along strike-slip fault boundaries of adjacent plates or microplates add more complexity to the overall geodynamic structure and kinematics of the Mediterranean and create a puzzle of crustal blocks independently moving, either uplifting or subsiding.

The eastern Mediterranean basins, namely the Ionian, Libyan and Levantine basins, are underlain by the last remnants of the Mesozoic Tethys Ocean, which is currently being consumed beneath the Calabrian Arc in the western Ionian Sea, the Hellenic Arc in the eastern Ionian, Libyan and western Levantine seas and the Cyprus Arc in the east Levantine Sea.

Evolution of the north-south trending Levantine coast of the Mediterranean's eastern edge is dominated by the Dead Sea Strike-Slip Fault (DS) and its secondary branches. This runs through the Middle East from south to north and accommodates the northward movement of the Arabian plate caused by the opening of the Red Sea. Large, destructive, magnitude $>6$ historical and recent earthquakes all along the DS are evidence of enhanced tectonic activity along the Dead Sea Fault and subsequent movements which have shaped the morphology of the Levantine coastline throughout the Quaternary. The oceanic floor of the Levantine basin is being consumed beneath Cyprus, along the Cyprus Arc.

The Hellenic Arc and the extending Aegean region behind it are tectonically and kinematically the most active areas in Europe. The main ongoing processes which dominate the geodynamic evolution of the Aegean and eastern Ionian seas are: the westward extrusion of the Anatolian continental block along the dextral strike-slip North Anatolian Fault boundary; the NNE subduction of the eastern Mediterranean lithosphere beneath the southwestward migrating Hellenic Arc at a rate of $3 \mathrm{~cm} /$ year to $4 \mathrm{~cm} /$ year; the resulting SSW-NNE 
extension of the Aegean back-arc region; the collision of northwestern Greece with the Apulian block in the northern Ionian Sea, particularly to the north of the Kephallinia Fault; and the incipient collision with the Libyan promontory south of Crete (e.g. McKenzie 1970; 1978; Dewey \& Şengör 1979; Le Pichon \& Angelier 1979; Le Pichon et al. 1982; Meulenkamp et al. 1988; Mascle \& Martin 1990; Meijer \& Wortel 1997; Jolivet 2001; Armijo et al. 2004, Kreemer \& Chamot-Rooke 2004).

The building up of stresses along the boundaries and in the interior of the crustal blocks leads to extensive deformation in the upper crust, expressed by very high seismicity and vertical and horizontal movements accommodated by normal, thrust and strike-slip faults. Continuous, long-term, tectonic uplift and/or subsidence by $1 \mathrm{~m} / \mathrm{kyr}$ or more is evident at many places along the Hellenic Arc and within the Aegean region and has been documented with mapping and dating of uplifted Pleistocene marine terraces or submerged pro-delta prograding sequences (e.g. Armijo et al. 1996, Lykousis et al. 2007; Lykousis 2009). Short-term, incremental, vertical movements in the Late Holocene modify the modeled post-LGM sea-level rise (Lambeck \& Purcell 2007), as postulated by uplifted or submerged paleoshorelines observed in numerous places along the Aegean coastline as in Crete, Rhodes, the Gulf of Corinth, Evia Island, the Aegean Islands, etc. (e.g. Pirazzoli et al. 1989; Kontogianni et al. 2002; Evelpidou et al. 2012a, b). The largest, abrupt, vertical tectonic dislocation recorded in the Mediterranean Sea occurred along the uplifting Hellenic Arc and resulted from the $365 \mathrm{AD}$ earthquake with magnitude $>8$ which uplifted and tilted the western half of Crete Island by up to $8 \mathrm{~m}$ (Shaw et al. 2008).

Quaternary tectonics in the Aegean, particularly in central Greece, has led to the formation of WNWESE trending neotectonic grabens which presently form elongate gulfs cutting across the Alpine structure of the Hellenides mountain chain: the $900 \mathrm{~m}$ deep Gulf of Corinth, the $450 \mathrm{~m}$ deep North Evia Gulf, the $400 \mathrm{~m}$ deep West Saronikos Gulf and the shallower Amvrakikos, South Evia and Pagasitikos gulfs have one characteristic in common: they are connected to the open sea through narrow and shallow straits which were exposed above the sea level during the LGM and possibly during earlier periods of low sea level. These presently marine water bodies were isolated lakes during the LGM with waterlevel considerably higher than the contemporaneous sea level (Perissoratis et al. 1993; Lykousis \& Anagnostou, 1993; Richter et al. 1993; Kapsimalis et al. 2005; Lykousis et al. 2007; Sakellariou et al. 2007a, b). Thus, the Holocene water/sea-level rise curve of these areas deviates significantly from the curves in adjacent areas.

The Calabrian Arc in the western Ionian Sea and central Mediterranean Sea marks the last phase in the subduction of the Ionian oceanic basin beneath the eastwards migrating Apennines-Maghrebides orogenic belt (Carminati \& Doglioni 2005). It is characterized by outward (east-southeastward) migration and frontal compression, arc-parallel extension, relative rotation of crustal fragments and fast uplift of onshore and shelf areas since the Mid Pleistocene (Westaway 1993; Sartori 2003; Viti et al. 2011).

The western Mediterranean comprises four, young (less than $30 \mathrm{Ma}$ old), extensional basins (Biju-Duval \& Montadert 1977): the Alboran basin, developed behind the westward-migrating Betic-Rif Arc; the Valencia Trough; the Algero-Provençal basin; and the Tyrrhenian basin, which opened progressively behind the eastwardmoving Apennines-Maghrebides Arc after the final collision of the Iberian and Eurasian plates along the Pyrenees (Carminati \& Doglioni 2005). The Tyrrhenian Sea is the result of rifting, back-arc extension and crustal thinning of the Alpine-Apennine orogenic belt above the westward-subducting Ionian oceanic lithosphere below the Calabrian Arc. Eastward migration of the latter led to the initiation of spreading and formation successively of the Vavilov and Marsili oceanic basins (Kastens et al. 1988; Kastens \& Mascle 1990; Sartori 1990; Jolivet 1993). Subduction-related volcanism migrated from west to southeast, namely from Sardinia to the presently active Aeolian Island Arc (Serri 1997).

Deformation in the west Mediterranean occurs mostly in the Alboran basin and along the North African Margin (Stich et al. 2005; 2007). In the south Iberian Margin, crustal deformation is mainly driven by the NW-SE convergence (4-5 mm/year) of the African and Eurasian plates (e.g. Argus et al. 1989). Convergence is accommodated over a wide deformation zone distributed 
among a number of active tectonic structures which are characterized by low to moderate seismicity (e.g. Buforn et al. 1995; 2004; Stich et al. 2005; 2007; 2010). Active faulting activity in the southeast Iberian Margin is dominated by the eastern Betic Shear Zone strikeslip system, a $450 \mathrm{~km}$-long fault zone, the splays of which, the Bajo Segura Fault to the north and the Carboneras Fault to the south, with slip-rates of about 1.3 $\mathrm{mm} /$ year (Moreno 2011), extend into the sea. The Yussuf Fault, a $250 \mathrm{~km}$-long, composite, dextral strike-slip fault, marks the boundary between the Alboran Sea and the Algerian Margin, and is capable of generating up to magnitude 7.4 earthquakes. The Al Idrissi Fault, running NNW-SSE in the Alboran Sea, is a left-lateral strikeslip structure (Martínez-García et al. 2011; Bartolomé et al. 2012) characterized by enhanced seismic activity with up to magnitude 6 earthquakes or larger. Both aforementioned faults in the Alboran Sea, along with other minor ones, have contributed significantly to the morphological configuration of the coastal areas.

\section{A Hydrologic System: The Black Sea since MIS 2}

The level of the Black Sea, to a certain extent, was controlled more by the regional climate than by global eustatic changes. From these interpreted results, Lericolais et al. (2009) have proposed a curve representing the water-level fluctuation in the Black Sea since the LGM. Today, in the light of the new results on ${ }^{14} \mathrm{C}$ calibration obtained by Soulet et al. (2011a) and leading to a revised calendar age for the last reconnection of the Black Sea to the Global Ocean at 9000 cal BP (Soulet et al. 2011b), it is possible to provide a calendar age sea-level curve for the Black Sea since the LGM (Fig. 2.15, see also Chapter 17, pages $[x x]-[x x])$ ).

The transition of the Black Sea system from a lacustrine to a marine environment is perhaps one of the best records of climate change on the European continent. Back at the Last Glacial Maximum, ca. 20,000 years ago, the Black Sea was probably a giant freshwater lake as proposed by Arkhangel'sky and Strakhov (1938) and

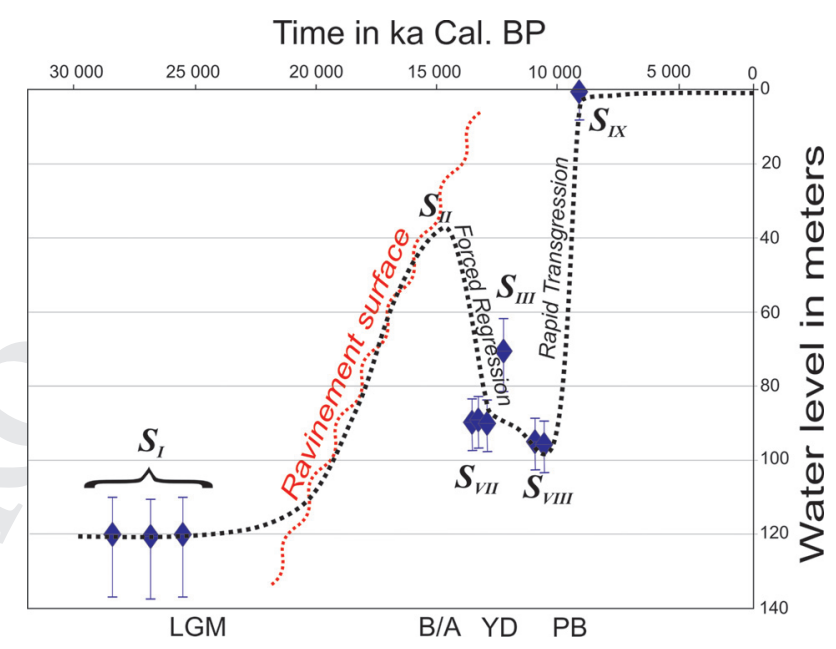

Fig. 2.15 Water-level fluctuation in the Black Sea since the LGM, deduced from the observations recovered on the northwestern Black Sea shelf. LGM = Last Glacial Maximum; B/A=Bølling-Allerød;

MWP-1a = Meltwater Pulse 1a; YD = Younger Dryas; PB = PreBoreal

$S_{\mid}$to $S_{I X}$ are the sequences interpreted and dated from the Romanian Black Sea shelf. Lericolais et al. (2009), revised version Lericolais et al. (2011).

confirmed by Soulet et al. (2010), and its water level stood around $120 \mathrm{~m}$ below today's level. The studies carried out on the Danube deep-sea fan (Popescu et al. 2001; Lericolais et al. 2013) confirm that the last channellevée system developed during MIS 2. Sediments supplied by the Danube River were transported to the deep basin through the Viteaz canyon (Popescu et al. 2004). The water brought to the Black Sea after the MWP$1 \mathrm{~A}$ at approximately $14,500 \mathrm{cal}$ BP (Bard et al. 1990) is supposed to have been sufficiently important that the water level rose to between $-40 \mathrm{~m}$ and $-20 \mathrm{~m}$, where the Dreissena layers were deposited. This last value for the transgression upper limit would have brought the level of the Black Sea even higher to the level of the Bosporus sill, and possible inflow of marine species like Mediterranean dinoflagellate populations can be envisaged (Popescu et al. 2003). The rise in the Black Sea water level, which stayed between fresh to brackish conditions, stopped deep-sea fan sedimentation.

Palynological studies conducted on BlaSON cores (Popescu et al. 2003) show that during the Younger Dryas a cool and drier climate prevailed. Northeastern rivers 
converged on the North Sea and the Ancylus Lake (Baltic Sea) (Jensen et al. 1999) giving reduced river input to the Black Sea resulting in a receding shoreline there. These assumptions are consistent with some evaporative drawdown of the Black Sea and correlated with the evidence of an authigenic aragonite layer present in all the cores studied (Giunta et al. 2007). This lowered sea level in the Black Sea persisted afterwards, evidenced by (1) continuously dry climatic conditions in the region which had started around 13,000 to $10,000 \mathrm{cal} \mathrm{BP}$, and (2) dune formation between 10,500 and $9000 \mathrm{cal}$ BP on the desiccated north-western Black Sea shelf at $100 \mathrm{~m}$. The Younger Dryas climatic event had lowered the Black Sea water level and the presence of the coastal sand dunes and wave-cut terrace confirm this lowstand. Preservation of these sand dunes and buried small incised valleys can be linked with a rapid transgression where the ravinement processes related to the water-level rise have had no time to erode sufficiently the sea bottom (Ahmed Benan \& Kocurek 2000; Lericolais et al. 2004). Around $9000 \mathrm{cal} \mathrm{BP}$, the surface waters of the Black Sea suddenly attained present-day conditions owing to an abrupt flooding of the Black Sea by Mediterranean waters, as shown by dinoflagellate cyst records (Popescu 2004) and as supposed by Ryan et al. (1997; 2003) who proposed $7500 \mathrm{cal} \mathrm{BP}$ — subsequently modified because no age reservoir correction was available until the work by Soulet et al. (2011a). Furthermore, Soulet et al. (2011b) and Nicholas et al. (2011) demonstrate that the Black Sea 'Lake' reconnection occurred in two steps, as follows: (1) Initial Marine Inflow (IMI) dated at 9000 cal BP followed by (2) a period of 900 to 1000 years, of increasing basin salinity that led to the disappearance of lacustrine species (DLS). This last event can also be correlated with the beginning of the sapropel deposit which is widespread and synchronous across slope and basin floor. The Black Sea basin would have been flooded in $~ 1000$ years, equalizing water levels in the Black Sea and Sea of Marmara. Such a sudden flood would have preserved lowstand marks on the Black Sea's northwestern shelf. Furthermore, the model developed by Siddall et al. (2004) suggests that about $60,000 \mathrm{~m}^{3}$ of water per second must have flowed into the Black Sea basin after the sill broke and it would have taken of the order of 33 years to equalize water levels in the Black Sea and the Sea of Marmara.

\section{Holocene Climate and Coastal Morphodynamics}

\section{Climate}

Climate models are one of the most powerful tools to simulate future climates. They have evolved in recent decades to become complicated software codes that try to represent as realistically as possible the different subsystems of the Earth's climate - the atmosphere, the ocean, the cryosphere, the terrestrial biosphere, the global carbon cycle, and others. Usually they are described as Atmosphere-Ocean General Circulation Models (AOGCM) or, more generally, Earth System Models (ESM) when they include carbon cycle and dynamic vegetation models. The models are driven by estimates of external forcing factors that comprise the greenhouse gases, volcanic activity, solar irradiance, land use and the configuration of the Earth's orbit. In the pre-industrial Holocene, the most important drivers were solar, volcanic and orbital forcing (Schmidt et al. 2011).

In spite of the complexity of present climate models, they still have clear limitations. One is their spatial resolution; at about $200 \mathrm{~km}$, it is not capable of capturing important aspects of regional climates such as the effect of coastlines and mountain ranges. Also, important dynamic processes like atmospheric turbulence, clouds and precipitation are represented in a simplified form. Most of the uncertainties in future climate projections stem from the different representation of the effects of clouds in the radiative and moisture balance in the climate models (Bindoff et al. 2007; Medeiros et al. 2008; Lauer \& Hamilton 2013).

The second limitation pertinent to the simulation of sea-level changes is the lack of a proper land-ice model in virtually all current climate models. This implies that the estimation of the eustatic contribution to sea-level changes requires additional inputs, for instance specific models of the polar ice caps and mountain glaciers, which 
in turn are partially driven by the simulated changes in air temperature. However, this approach cannot completely capture important processes for the mass balance of ice caps and glaciers. The resolution of the simulated temperature field is not adequate for the requirements of a glacier model. Glaciers are also partially driven by precipitation, which is not well represented in global climate models. Also, air temperature directly drives the surface melt over ice caps (van den Broeke et al. 2009) but its influence on the ice rheology is much more subtle and not totally understood (Joughin et al. 2012).

As a result, as reflected in the series of reports of the Intergovernmental Panel on Climate Change (IPCC) (Church et al. 2013), global climate models are more capable of simulating the thermal expansion of the water column of the global oceans. The other contributions to mean sea level due to climate changes mentioned above have to be estimated by other means. This limitation pertains not only to the globally averaged sea level, but also to the large-scale spatial variations of sea-level change due to the self-gravitational effect (Mitrovica et al. 2001). Due to this effect, ice melting from the Antarctic ice sheet is most strongly felt in the sea level of the Northern Hemisphere. It is smaller in the Southern Hemisphere and sea level may even fall near Antarctica when landice melts there. Likewise, the melting of Greenland ice is most strongly felt in the sea level in the Southern Hemisphere, whereas its direct effect in western Europe is much smaller, about $10 \%$ to $20 \%$ of the global sealevel rise caused by Greenland ice melting (Mitrovica et al. 2001). More complicated spatial patterns result from the melting of mountain glaciers, which are concentrated in a few regions scattered around the globe - the Himalayas, the Andes and Alaska. For the focus of this book on western European coasts, it is thus mainly the melting of the Antarctic ice sheet, in particular from the West Antarctic ice sheet, that is of relevance. However, it is not easy to estimate the different contributions of polar ice caps and glaciers to global ice melting, given a global level of warming or cooling.

In seas like the Baltic and the Mediterranean, mean sea-level changes at monthly to decadal timescales can be modulated by prevailing wind stress and air pressure gradients (barometric effect). Also, coastal sediment transport is strongly modulated by prevailing wind forcing. These are generally considered to be much more realistically simulated by climate models.

Therefore, when considering the sea level simulated by present climate models it has to be borne in mind that the different processes that are involved in sea-level changes may be simulated with different levels of uncertainty, ranging from the most uncertain, that related to mass loss from polar ice caps, to the relatively most certain, that related to the thermal expansion of the water column.

Most of the paleoclimate simulations with comprehensive atmosphere-ocean coupled models are timeslice simulations. The models run with external drivers frozen-in to the values attained at a certain time, for instance $6000 \mathrm{BP}$. The aim of these simulations is thus not to simulate climate evolution through time, but to generate a certain number of years of stationary climate at that particular point in time. For instance, the Climate Model Intercomparison Project Phase 5 (CMIP5), whose simulations are being used in the Fifth Assessment Report of the IPCC, contains a set of simulations denoted Mid Holocene that are time-slice simulations.

On the other hand, in transient simulations the external forcing is continuously changed to represent the real changes of the external forcing that occurred in the past. There are only very few transient simulations with AOGCMs covering the Holocene or even the period between the Holocene Thermal Maximum - about 6000 years ago - and the present. These simulations have been conducted with AOGCMs with a horizontal resolution coarser than the resolution used for future climate projections, due to the demanding computing resources for a simulation several thousand model-years long. Nevertheless, these simulations are indeed useful to estimate the range of magnitude of the relevant processes that may have influenced sea level in the past. In the following we present some select aspects of one of these simulations that may be relevant for sea-level and coastal thermodynamics in West European coastal seas.

The model ECHO-G, composed of the atmospheric model ECHAM4 and the ocean model HOPE was used to simulate the last 7000 years, driven by orbital forcing, solar variations and greenhouse gases (Fig. 2.16, see also Hünicke et al. (2011)). 


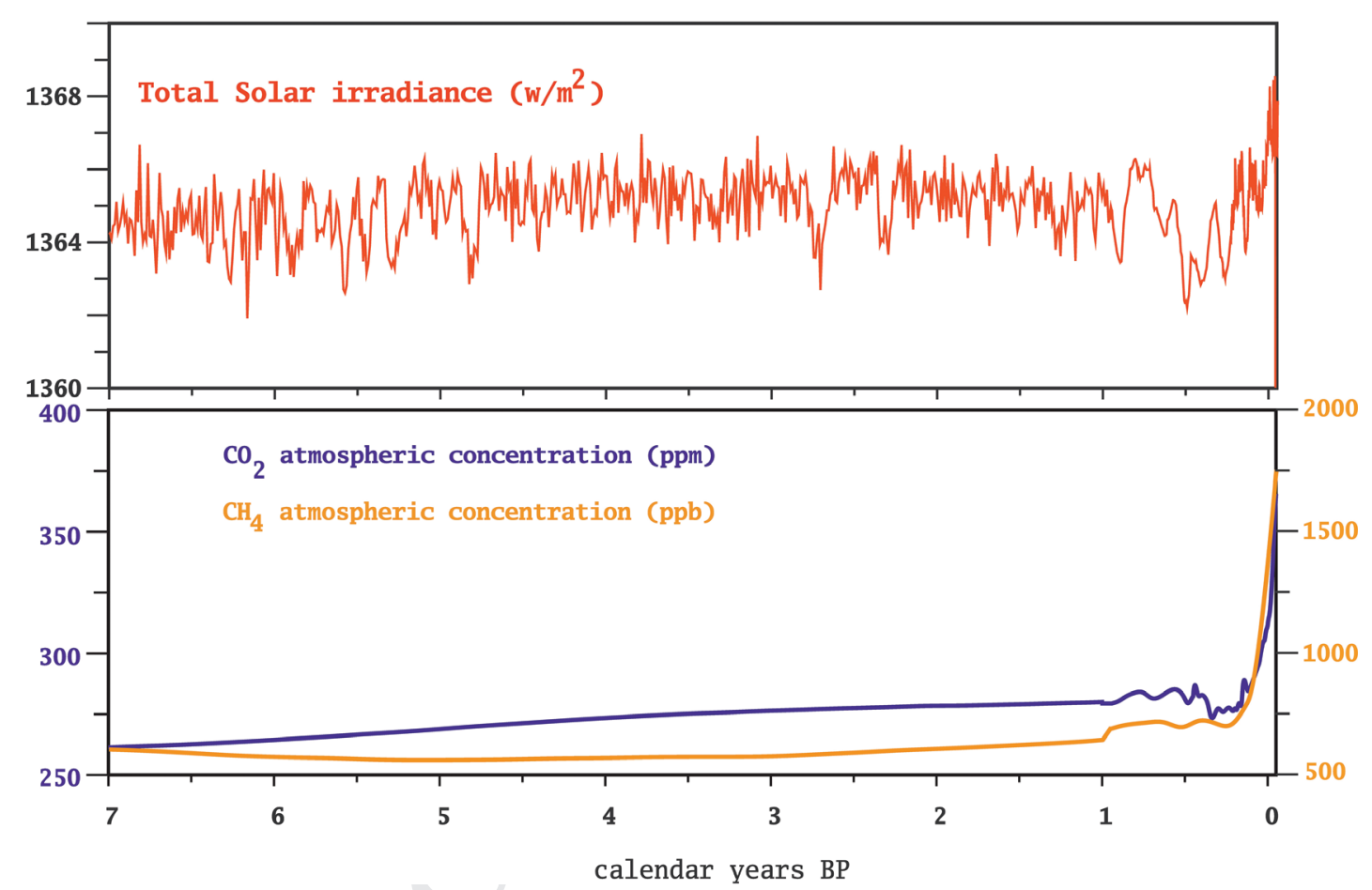

Fig. 2.16 Time series of model ECHO-G forcings (orbital forcing, solar variations and greenhouse gases). These data are derived from the analysis of cosmogenic isotopes in ice cores and tree rings (solar irradiance, Solanki et al. 2004), and of the air bubbles trapped in polar ice (Indermühle et al. 1999). There is still some uncertainty regarding the amplitude of past solar variations and thus this series has to be considered as one possibility among others. Schmidt et al. (2011).

Figure 2.17 shows AOGCM ECHO-G simulation results of Northern Hemisphere mean temperature in winter and summer, with a horizontal resolution of 3.75 degrees. The model was driven by estimations of part orbital forcing, solar variations and greenhouse gases. In this simulation no volcanic forcing was included due to the lack of reliable reconstructions over the past millennia. However, it is generally believed that volcanic forcing may affect temperatures at decadal or maybe multi-decadal timescales, but not produce multi-centennial or longer temperature trends.

The variations in the near-surface temperature are of the order of $1^{\circ} \mathrm{K}$ at most, which would translate into an expansion of the water column of the order of a few tenths of a centimeter, depending on how deep into the ocean the temperature variations would penetrate. This thermal expansion is an order of magnitude smaller than the estimated sea-level variations over the last 7000 years in the Baltic Sea region due to melting land ice and isostatic glacial rebound, and thus it likely played a minor role.

The evolution of the summer temperature in the Northern Hemisphere, with warm summers around the Holocene Thermal Maximum and decreasing temperatures thereafter, is consistent with orbital forcing, which caused higher summer insolation in the Northern Hemisphere at high latitudes - the perihelion occurred in the summer season, compared to January today. It is also consistent with pollen-based reconstructions in Europe (Davis et al. 2003). On the other hand, the evolution of winter temperatures, though similarly consistent with orbital forcing, is not totally in agreement with the evidence provided by proxy records, which indicate warmer winters in the Holocene Thermal Maximum in Europe. Most climate models from the CMIP5 model suite are not capable of producing these reconstructed warm mean winter temperatures in the Mid Holocene, this being still an open question. Probably, 


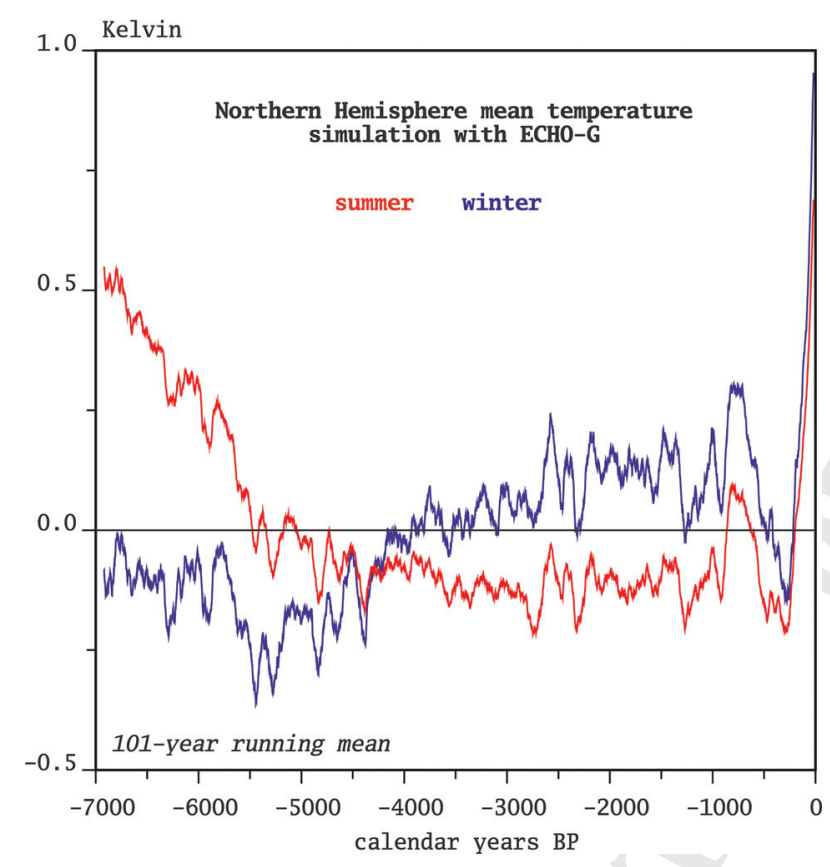

Fig. 2.17 Northern Hemisphere mean temperature in winter and summer simulated by the simulation with the atmosphere-ocean general circulation model ECHO-G driven by orbital, solar and greenhouse gas forcings since 7 ka BP.

other mechanisms additional to pure orbital forcing may have played a role in winter.

More important for sea-level variations in regional seas and for nearshore sediment transport are changes in the prevailing wind strength and direction. The wind regime in the North Atlantic-European sector can be described by the dominating patterns of variations of the sea-level-pressure field, of which the best known is the North Atlantic Oscillation (NAO). The NAO index statistically describes the meridional pressure gradient between the subtropical anticyclone and the subpolar low pressure cell, and thus also describes the strength of the westerly winds in western Europe. The same simulation with the AOGCM ECHO-G indicates that, in the winter season, the state of the NAO may have been turning progressively more negative (weakening pressure gradient and weakening zonal winds) over the last 7000 years, although the millennial-scale trend is weak (Fig. 2.18). This is in qualitative agreement with the findings of Olsen et al. (2012). On the other hand, the summer NAO has undergone a weakening trend from the beginning of the simulation to as recently as $4000 \mathrm{BP}$, strengthening thereafter. During the whole simulation, more importantly, the summer NAO index has been clearly negative with respect to present values, meaning that the meridional sea-level-pressure gradient would have been weaker than present, and thus the zonal summer winds over western Europe would have been accordingly weaker as well.

It is these weakened zonal winds in summer that most strongly affect the annual mean winds. Figure 2.19 displays the annual mean $10-\mathrm{m}$ winds in the Mid Holocene (6500-5500 BP) as deviations relative to the twentieth-century mean. The wind deviations over northern Europe are easterly, meaning the mean westerly winds would have been weaker than present. On the other hand, southern Europe and the Mediterranean region experienced stronger westerlies, with a stronger influence of the air masses of North Atlantic.

\section{Coastal morphodynamics}

A globally stabilized mean sea level in the Mid-to-Late Holocene restricts sea-surface wave actions to a smallrange coastal area and a limited vertical range (i.e. from low-lying coastal lands with altitude less than $\sim 10 \mathrm{~m}$ above mean sea level to the storm wave base at midshelf that is $\sim 100 \mathrm{~m}$ below the mean sea level). Coasts built up by soft sediments such as Quaternary deposits are constantly shaped by winds, tides and waves and, on a longer timescale, can shift landward or seaward due to oscillations of the sea level and variations in the sediment supply, destroying also existing archaeological sites. Integrated high-resolution morphodynamic modeling approaches can help to reconstruct the development of paleocoastal landscapes, climate and glacio-isostasy, and can demonstrate favorable conditions for the preservation of paleolandscapes.

Existing coastal morphodynamic models can be classified into three types: (1) process-based; (2) behaviororiented and (3) a hybrid of the former two types. The advantages as well as shortcomings of the first two model types have been widely revealed and discussed (e.g. de Vriend 2001; Fagherazzi \& Overeem 2007). 


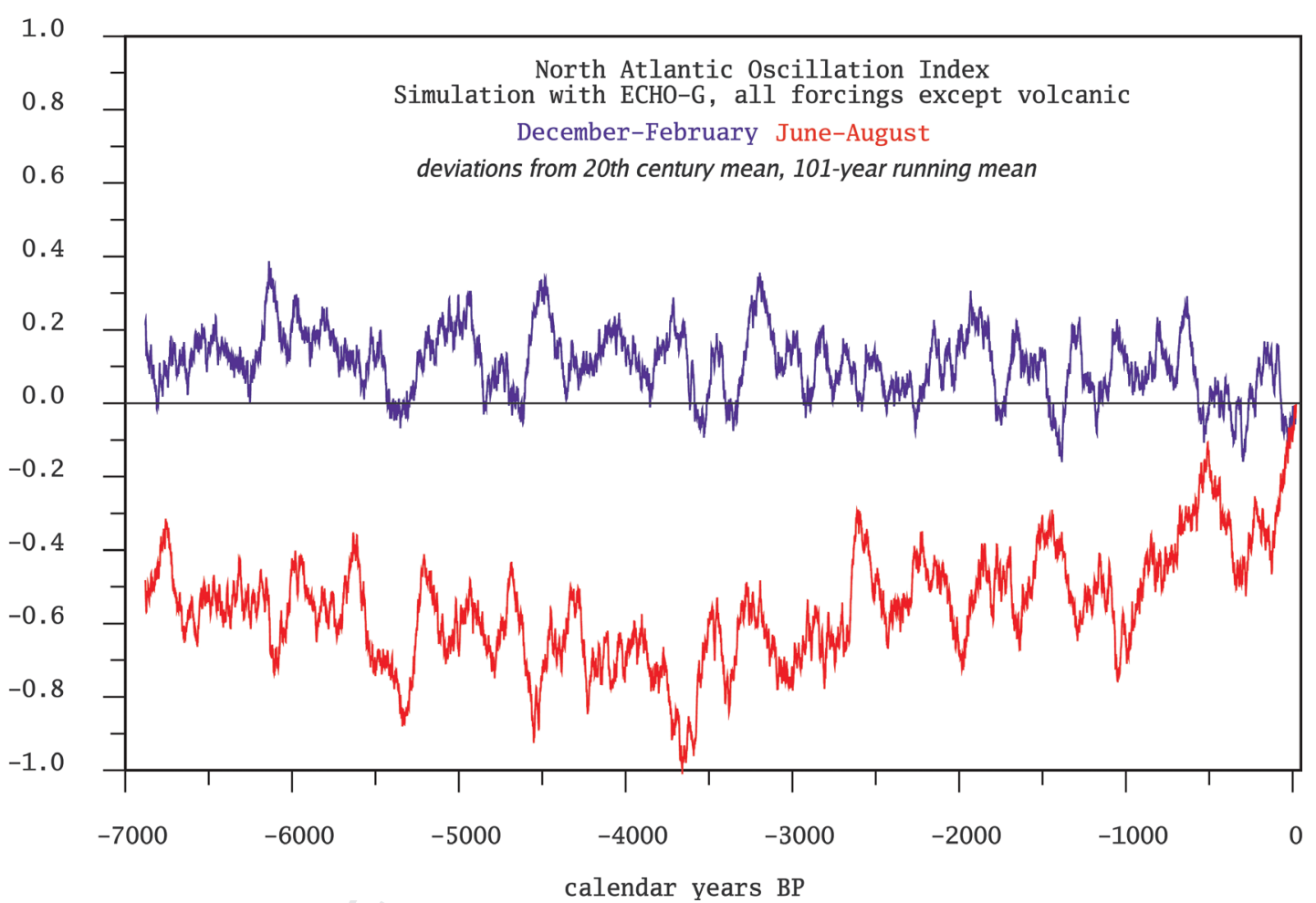

Fig. 2.18 Index of the North Atlantic Oscillation since 7 ka BP simulated by the model ECHO-G in winter (December-February) and summer (June-August).

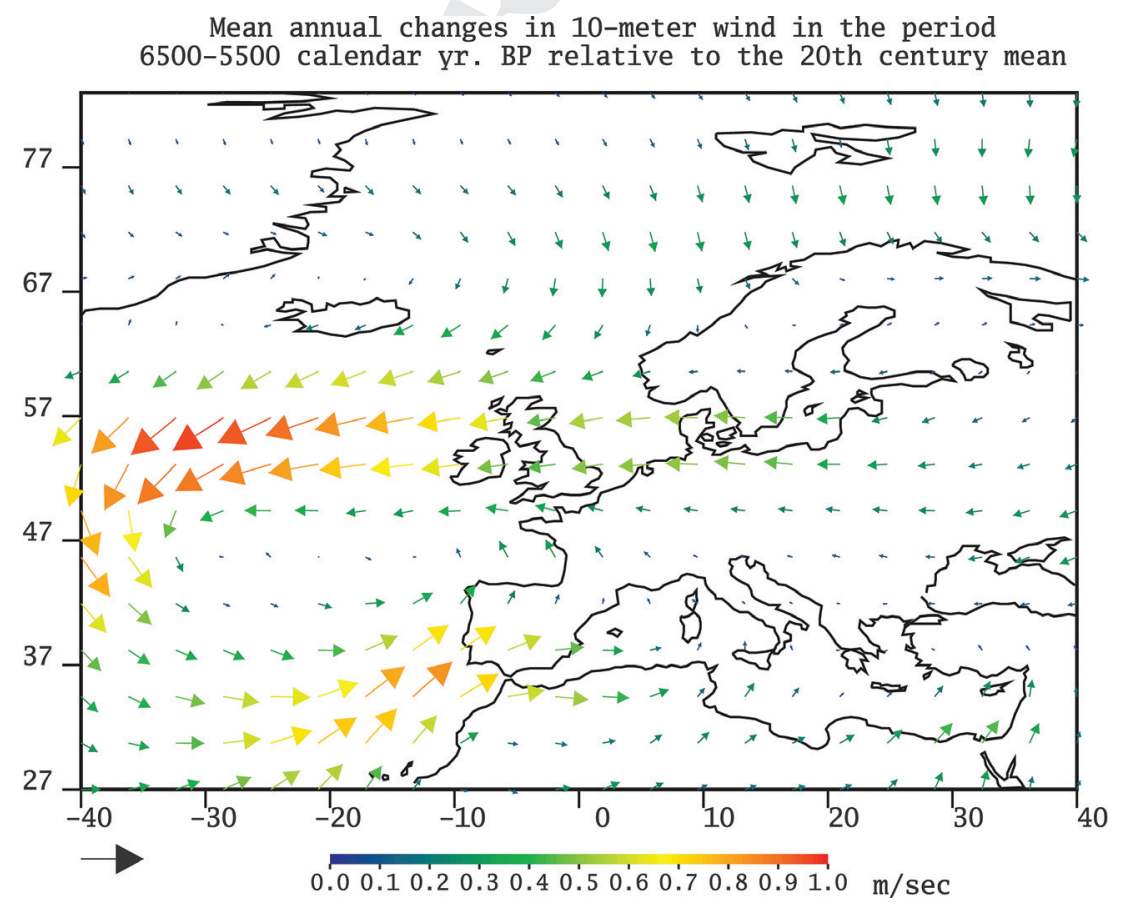

Fig. 2.19 Changes in the annual mean 10-m winds in the period 6.5-5.5 ka BP relative to present simulated by the model ECHO-G. 

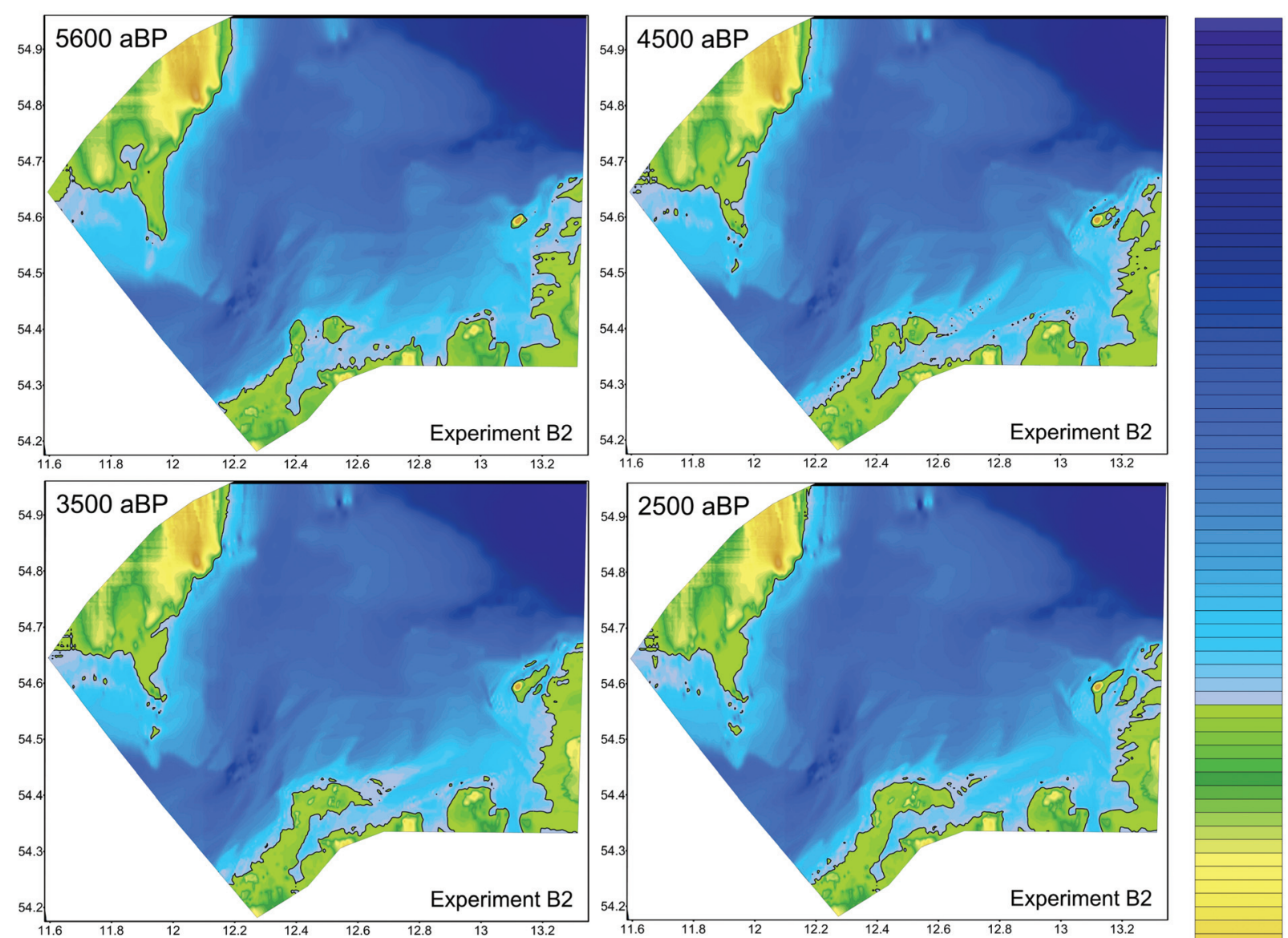

$-50$
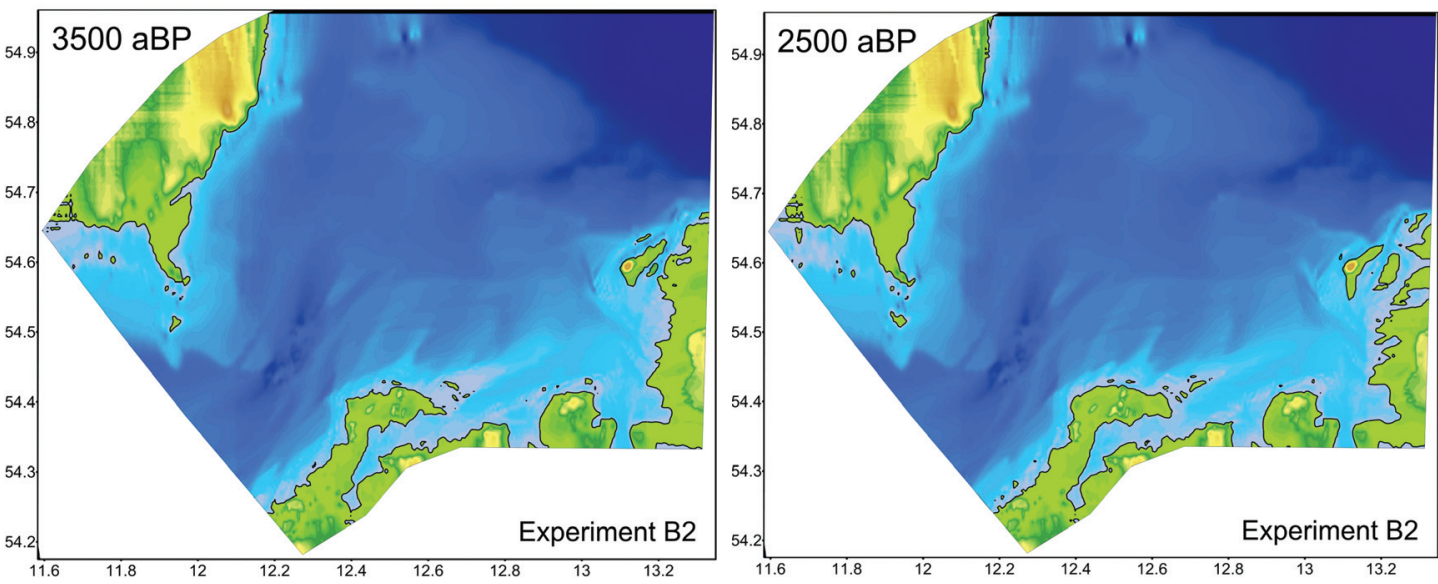

$-45$

$-40$

$-35$

$-30$

$-25$

$-20$

$-15$

$-10$

$-5$

0

5
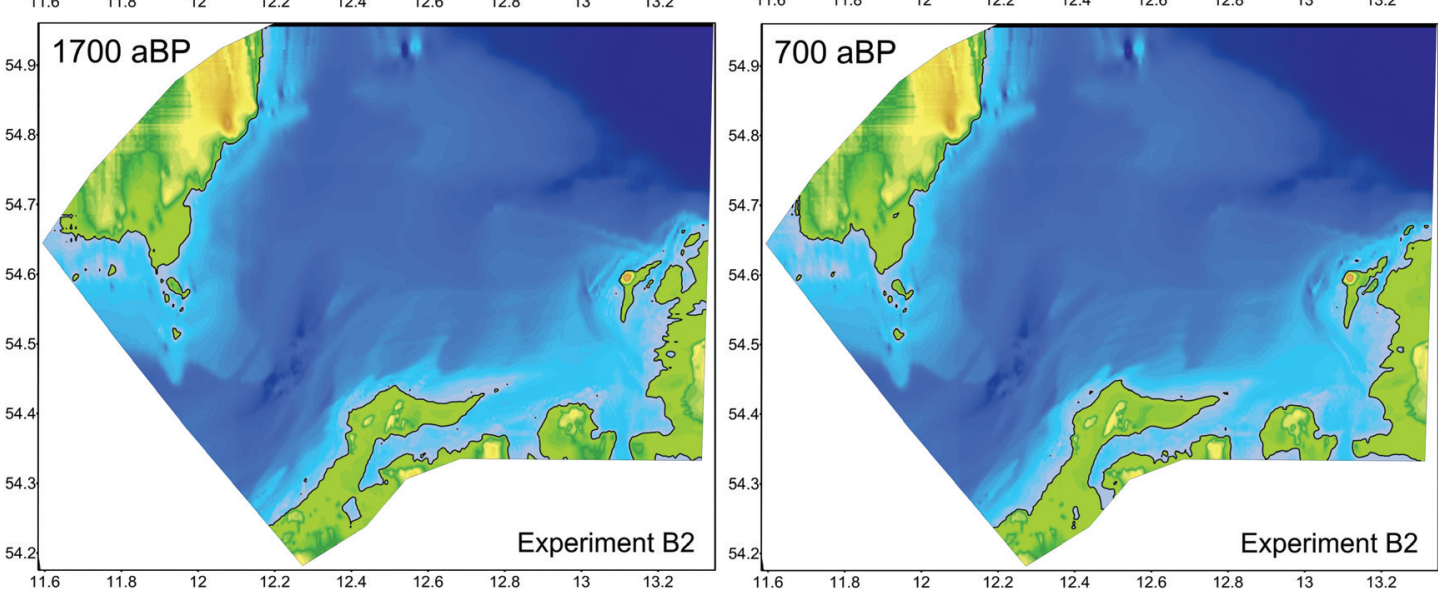

Fig. 2.20 Simulated morphological evolution of the Darss-Zingst Peninsula (location marked in Fig. 2.11) since 6 ka BP. Modified from Zhang et al. (2014). 
Although high-resolution process-based models are reliable in capturing short-term (from hourly to daily scale) coastal morphodynamics, their application to the longerterm (from annual up to millennial scale) is severely hindered. The reason for this originates not only from the numerical errors induced by the solutions for the partial differential equations, but also from insufficient knowledge of the complexity of the natural system. Great efforts have been made by researchers in recent decades to improve the reliability of high-resolution coastal morphodynamic models, e.g. 'reduction' concepts are introduced by de Vriend et al. (1993a,b) to reduce the errors of process-based models in long-term simulation; techniques of morphological update acceleration have been proposed by Roelvink (2006) to increase the long-term computational efficiency. For complex coastal systems, hybrid modeling, which combines advantages both of process-based and behavior-oriented models, has shown promising results for long-term modeling (e.g. Jiménez \& Sánchez-Arcilla 2004; Karunarathna et al. 2008).

Recently Zhang et al. (2010; 2012) have developed a modeling methodology for the simulation of longterm morphological evolution of wave-dominated coasts and applied it successfully to hindcast the morphological evolution of two barrier island systems in the southern inundated Baltic Sea (the Darss-Zingst Peninsula and the Swina Gate barrier) on a centennial (Zhang et al. 2011) and a millennium scale (Zhang et al. 2014), respectively. The methodology consists of three major components: (1) an analysis of the key boundary conditions driving the morphological evolution of the study area based on statistical analysis of meteorological and sedimentological data; (2) a multi-scale high-resolution hybrid model in which 'reduction' concepts, techniques for morphological update acceleration and approaches for maintaining computational stability are implemented; and (3) a sensitivity study in which a large number of simulation iterations are carried out to derive an optimum parameter setting for the model.

A case study on the Darss-Zingst Peninsula is briefly introduced here to explain the use of high-resolution models for investigation of medium-to-long-term coastal morphodynamics. For details of the work the reader is referred to Zhang et al. (2014). In order to initiate a historical hindcast of coastal morphological evolution, Zhang et al. use a paleo-Digital Elevation Model (DEM) serving as the initial condition and reconstructed from a compilation of recent digital elevation data sets, an eustatic sea-level curve, an isostatic map and dated sediment cores. Representative wind series have been generated based on a statistical analysis of paleo-wind data from a simulation with the coupled atmosphereocean general circulation model ECHO-G over the last 7000 years. These wind data were calibrated by proxies from lithostratigraphic studies of sediment cores from the central Baltic Sea, and used as climate driving conditions for the morphodynamic model. Based on the reconstructed paleo-DEM and the representative climatic driving conditions, the model is applied to reconstruct the Holocene morphogenesis of the Darss-Zingst Peninsula since 6000 BP. Simulation results (Fig. 2.20) indicate that the development of the barrier system is a combination of long-term effects of climate change, isostatic crustal movement, wave dynamics and eolian transport with short-term effects of extreme wind events, i.e. storms. The information derived from the modeling study may provide valuable prerequisites for planning and executing archaeological surveys on the continental shelf.

\section{Conclusion}

The environment of the European continental shelf changed drastically after the Last Glacial Maximum: inland ice melted and the resulting drainage system re-shaped the landscape. Ice lakes formed in front of the decaying glaciers, the rising sea level caused a submergence of large parts of the continental shelf, and freshwater lakes converted to brackish-marine water reservoirs. The most important processes for the change of coastlines comprise the interrelation of climatically controlled eustatic sea-level rise and vertical crustal displacement of the Earth's crust. The latter is dependent on the position of a site under investigation related to (1) the decaying ice shield, and (2) the tectono-stratigraphic units of Europe. Coastlines on Proto-, Paleo- and 
Meso-Europe are mainly influenced by glacio- and hydroisostatic adjustment interacting with eustatic change. In Neo-Europe - that is in particular along the coasts of the Mediterranean Sea - regional and local tectonics due to the collision of Africa and Eurasia determine the pattern of uplift and subsidence of crustal units of different spatial dimensions. So, individual relative sea-level curves reflect the puzzle of tectonic units of the Mediterranean Sea. Generally on the European shelf, external forces causing glacio-(hydro)-isostatic adjustments, and eustatic changes are superimposed on the internally induced tectonic dynamics. Additionally, on a shorter timescale, processes of sediment dynamics driven by atmospheric and hydrographic forces have to be considered.

According to the factors affecting changes of relative sea level, the different driving forces that have shaped the European shorelines and the variable exposed areas of the continental shelf can be separated both temporally as well as regionally.

Glacio-isostatic adjustment caused by unloading (melting inland ice) and loading (seawater volume increase) was the dominant factor affecting coastline change from the Late Glacial Period to the Atlantic Period. Water-level change of dammed isolated freshwater lakes was a major factor influencing paleogeographic patterns in the Baltic and Black seas from the Late Pleistocene to the Boreal.

Climatically controlled eustatic sea-level rise was the major factor determining the inundation of the shelf in the North Sea and Atlantic during deglaciation, extending up to the Subatlantic Period.

Along Mediterranean coasts, tectonic deformation of the Earth's crust was superimposed on the postglacial sealevel rise continuously since the glacial maximum.

Coasts built-up of soft materials such as Pleistocene deposits are reshaped by the dynamics of nearshore processes driven by atmospheric circulation. These forces have had their main effect on coastline development mainly since the sea-level rise slowed during the Subatlantic Period.

Integrated modeling approaches of climate and glacio-isostasy can demonstrate favorable conditions for the preservation of submerged paleolandscapes. These approaches may provide valuable prerequisites for planning and executing archaeological surveys on the continental shelf. These models describe changes in Earth's climate during the Late Pleistocene and the corresponding melting of continental ice shields marking the end of the last glaciation. The parameterization of the load due the redistribution of water by melting of continental ice sheets is accomplished by the interpretation of geological proxy data. Such models compute the changing rates of relative sea level along the continental margins and display the transgression or regression of the coastline. For times of relatively rapid sea-level rise - as during the Late Pleistocene and Early Holocene - paleolandscapes are more likely to preserve their former shape than during periods of slow sea-level rise. From the Mid-to-Late Holocene - a period of relatively slow sea-level rise - migrating highly dynamic shorelines rework intensively the substrate of the coastal zone, eventually destroying many archaeological sites and burying others. The application of long-term morphodynamic sediment models can help to identify paleocoasts with higher potential for the conservation of archaeological sites and paleolandscapes.

\section{References}

Ahmed Benan, C. A. \& Kocurek, G. 2000. Catastrophic flooding of an aeolian dune field: Jurassic Entrada and Todilto Formations, Ghost Ranch, New Mexico, USA. Sedimentology 47:1069-1080.

Alley, R. B., Anandakrishnan, S. \& Jung, P. 2001. Stochastic resonance in the North Atlantic. Paleoceanography 16:190-198.

Andersen, B. G. \& Borns Jr., H. W. 1997. The Ice Age World. Scandinavian University Press: Oslo.

Andrén, T., Björck, S., Andrén, E., Conley, D., Zillén, L. \& Anjar J. 2011. The Development of the Baltic Sea Basin During the Last 130 ka. In Harff, J., Björck, S. \& Hoth, P. (eds.) The Baltic Sea Basin. pp. 75-97. Springer: New York.

Antonioli, F., Ferranti, L., Fontana, A. et al. 2009a. Holocene relative sea-level changes and vertical movements along the Italian coastline. Quaternary International 206:102-133. 
Antonioli, F., Amorosi, A., Correggiari, A. et al. 2009b. Relative sea-level rise and asymmetric subsidence in the northern Adriatic. Rendiconti online della Società Geologica Italiana 9:5-7.

Argus, D. F., Gordon, R. G., DeMets, C. \& Stein, S. 1989. Closure of the Africa-Eurasia-North America plate motion circuit and tectonics of the Gloria Fault. Journal of Geophysical Research 94(B5):5585-5602.

Arkhangel'sky, A. D. \& Strakhov, N. M. 1938. Geological Structure and Evolution of the Black Sea. Geological Institute of the Russian Academy of Sciences of the USSR: Moscow-Leningrad (in Russian).

Armijo, R., Meyer, B., King, G. C. P., Rigo, A. \& Papanastassiou, D. 1996. Quaternary evolution of the Corinth rift and its implications for the Late Cenozoic evolution of the Aegean. Geophysical Journal International 126:11-53.

Armijo, R., Flerit, F., King, G., \& Meyer, B. 2004. Linear elastic fracture mechanics explains the past and present evolution of the Aegean. Earth and Planetary Science Letters 217:85-95.

Bakker, M., Meekes, S., van Heteren, S. et al. 2012. Towards a three-dimensional geological model of the North Sea subsurface. In Kranenburg, W. M., Horstman, E. M. \& Wijnberg, K. M. (eds.) NCKdays 2012: Crossing borders in coastal research Jubilee conference proceedings (University of Twente). $13^{\text {th }}-16^{\text {th }}$ March 2012, Enschede (the Netherlands), pp. 81-84.

Bard, E., Hamelin, B., Fairbanks, R. G. \& Zinder, A. 1990. A calibration of the ${ }^{14} \mathrm{C}$ timescale over the past 30,000 years using mass spectrometric U-Th ages from Barbados corals. Nature 345:405-410.

Bartolomé, R., Gràcia, E., Stich, D. et al. 2012. Evidence for active strike-slip faulting along the Eurasia-Africa convergence zone: Implications for seismic hazard in the southwest Iberian Margin. Geology 40:495-498.

Barton, P. \& Woods, R. 1984. Tectonic evolution of the North Sea basin: crustal stretching and subsidence. Geophysical Journal of the Royal Astronomical Society 79:987-1022.

Berger, A. \& Loutre, M. F. 1991. Insolation values for the climate of the last 10 million years. Quaternary Science Reviews 10:297-317.
Biju-Duval, B. \& Montadert, L. (eds.) 1977. Structural History of the Mediterranean Basins. Editions Technip: Paris.

Bindoff, N. L., Willebrand, J., Artale, V. et al. 2007. Observations: Oceanic Climate Change and Sea Level. In Solomon, S., Qin, D., Manning, M. et al. (eds.) Climate Change 2007: The Physical Science Basis. Contribution of Working Group I to the Fourth Assessment Report of the Intergovernmental Panel on Climate Change. Cambridge University Press: Cambridge/New York.

Bond, G., Showers, W., Cheseby, M. et al. 1997. A pervasive millennial-scale cycle in North Atlantic Holocene and glacial climates. Science 278:1257-1266.

Bond, G., Kromer, B., Beer, J. et al. 2001. Persistent solar influence on North Atlantic climate during the Holocene. Science 294:2130-2136.

Brooks, C. E. P. 1926. Climate Through The Ages: A Study of the Climatic Factors and Their Variations. Ernest Benn Ltd: London.

Brossolo, L., Mascle, J. \& Loubtrieu, B. 2012. MorphoBathymetric map of the Mediterranean Sea (scale 1:4,000,000), 1st Edition. CGMW/UNESCO.

Buforn, E., Sanz de Galdeano, C. \& Udías, A. 1995. Seismotectonics of the Ibero-Maghrebian region. Tectonophysics 248:247-261.

Buforn, E., Bezzeghoud, M., Udías, A. \& Pro, C. 2004. Seismic sources on the Iberia-African Plate boundary and their tectonic implications. Pure \& Applied Geophysics 161:623-646.

Cameron, T. D., Crosby, A., Balson, P. S. et al. 1992. UK Offshore Regional report: The Geology of the Southern North Sea. HMSO for the British Geological Survey: London.

Carlson, A. E. 2011. Ice sheets and sea level in Earth's past. Nature Education Knowledge 3(10):3.

Carminati, E. \& Doglioni, C. 2005. Europe - Mediterranean tectonics. In Selley, R. C. Cocks, L. R. M. \& Plimer, I. R. (eds.) Encyclopedia of Geology. pp. 135-146. Elsevier: Oxford.

Church, J. A., Clark, P. U., Cazenave, A. et al. 2013. Sea Level Change. In Stocker, T. F., Qin, D., Plattner, G.-K. et al. (eds.) Climate Change 2013: The Physical Science Basis. Contribution of Working Group I to 
the Fifth Assessment Report of the Intergovernmental Panel on Climate Change. Cambridge University Press: Cambridge/New York.

Clark, P. U., McCabe, A. M., Mix, A. C. \& Weaver, A. J. 2004. Rapid rise of sea level 19,000 years ago and its global implications. Science 304:1141-1144.

Clark, P. U., Dyke, A. S., Shakun, J. D. et al. 2009. The last glacial maximum. Science 325:710-714.

Crowley, T. J. \& North, G. R. 1991. Paleoclimatology. Oxford University Press: New York.

Cuffey, K. M., Clow, G. D., Alley, R. B., Stuiver, M., Waddington, E. D. \& Saltus, R. W. 1995. Large Arctic temperature change at the Wisconsin-Holocene glacial transition. Science 270:455-458.

Davis, B. A. S., Brewer, S., Stevenson, A. C. \& Guiot, J. 2003. The temperature of Europe during the Holocene reconstructed from pollen data. Quaternary Science Reviews 22:1701-1716.

de Vriend, H. J. 2001. Long-term morphological prediction. In Seminara, G. \& Blondeaux, P. (eds.) River, Coastal and Estuarine Morpho-dynamics. pp. 163-190. Springer: Berlin Heidelberg.

de Vriend, H. J., Copabianco, M., Chesher, T., De Swart, H. E., Latteux, B. \& Stive, M. J. F. 1993a. Approaches to long-term modelling of coastal morphology. Coastal Engineering 21:225-269.

de Vriend, H. J., Zyserman, J., Nicholson, J., Roelvink, J. A., Pechon, P. \& Southgate, H. N. 1993b. Mediumterm 2DH coastal-area modelling. Coastal Engineering 21:193-224.

Dewey, J. F. \& Şengör, A. M. C. 1979. Aegean and surrounding regions: Complex multiplate and continuum tectonics in a convergent zone. Geological Society of America Bulletin 90:84-92.

Dyke, A. S. 2004. An outline of North American deglaciation with emphasis on central and Northern Canada. In Ehlers, J. \& Gibbard, P. L. (eds.) Quaternary Glaciations: Extent and Chronology Part II: North America. p. 373-424. Elsevier: Amsterdam.

Evelpidou, N., Vassilopoulos, A. \& Pirazzoli, P. A. 2012a. Holocene emergence in Euboea island (Greece). Marine Geology 295-298:14-19.

Evelpidou, N., Vassilopoulos, A. \& Pirazzoli, P. A. 2012b. Submerged notches on the coast of Skyros
Island (Greece) as evidence for Holocene subsidence. Geomorphology 141-142:81-87.

Fagherazzi, S. \& Overeem, I. 2007. Models of deltaic and inner continental shelf landform evolution. Annual Review of Earth and Planetary Science 35:685-715.

Fairbanks, R. G. 1989. A 17,000-year glacio-eustatic sea level record: influence of glacial melting rates on the Younger Dryas event and deep-ocean circulation. Nature 342:637-642.

Farrell, W. E. \& Clark, J. A. 1976. On postglacial sea level. Geophysical Journal of the Royal Astronomical Society 46:647-667.

Ferranti, L., Antonioli, F., Mauz, B. et al. 2006. Markers of the last interglacial sea-level high stand along the coast of Italy: Tectonic implications. Quaternary International 145-146:30-54.

Franke, W. 1989. Tectonostratigraphic units in the Variscan belt of central Europe. Geological Society of America Special Papers 230:67-90.

Gaffney V., Thomson, K. \& Fitch, S. (eds.) 2007. Mapping Doggerland: The Mesolithic Landscapes of the Southern North Sea. Archaeopress: Oxford.

Gibbard, P. L. 1988. The history of the great northwest European rivers during the past three million years. Philosophical Transactions of the Royal Society, London B318:559-602.

Giunta, S., Morigi, C., Negri, A., Guichard, F. \& Lericolais, G. 2007. Holocene biostratigraphy and paleoenvironmental changes in the Black Sea based on calcareous nannoplankton. Marine Micropaleontology 63:91-110.

Grant, K. M., Rohling, E. J., Bar-Matthews, M. et al. 2012. Rapid coupling between ice volume and polar temperature over the past 150,000 years. Nature 491:744-747.

Groh, A., Dietrich, R. \& Richter, A. 2011. Geodetic evidence and modelling of sea-level changes and loadinduced crustal deformations in the southern Baltic Sea. In Harff, J. \& Lüth, F. (eds.) Sinking Coasts Geosphere, Ecosphere and Anthroposphere of the Holocene Southern Baltic Sea II. pp. 17-40. Bericht der RömischGermanische Kommission (vol. 92).

Hanebuth, T. J. J., Voris, H. K., Yokoyama, Y., Saito, Y. \& Okuno, J. 2011. Formation and fate of sedimentary 
depocentres on Southeast Asia's Sunda Shelf over the past sea-level cycle and biogeographic implications. Earth-Science Reviews 104:92-110.

Harff, J., Lemke, W., Lampe, R. et al. 2007. The Baltic Sea coast - A model of interrelations among geosphere, climate, and anthroposphere. Geological Society of America Special Papers 426:133-142.

Harff, J., Endler, R., Emelyanov, E. et al. 2011. Late Quaternary climate variations reflected in Baltic Sea sediments. In Harff, J., Björck, S. \& Hoth, P. (eds,) The Baltic Sea Basin. pp. 99-132. Springer: Berlin Heidelberg.

Hünicke, B., Zorita, E. \& Haeseler, S. 2011. Holocene climate simulations for the Baltic Sea Region application for sea level and verification of proxy data. In Harff, J \& Lüth, F. (eds.) Sinking Coasts - Geosphere, Ecosphere and Anthroposphere of the Holocene Southern Baltic Sea II. pp. 211-249. Bericht der Römisch-Germanische Kommission (vol. 92).

Indermühle, A., Stocker, T. F., Joos, F. et al. 1999. Holocene carbon-cycle dynamics based on $\mathrm{CO}_{2}$ trapped in ice at Taylor Dome, Antarctica. Nature 398:121-126.

Jensen, J. B., Bennike, O., Witkowski, A., Lemke, W. \& Kuijpers, A. 1999. Early Holocene history of the southwestern Baltic Sea: The Ancylus Lake stage. Boreas 28:437-453.

Jiménez, J. A. \& Sánchez-Arcilla, A. 2004. A long-term (decadal scale) evolution model for microtidal barrier systems. Coastal Engineering 51:749-764.

Jolivet, L. 1993. Extension of thickened continental crust, from brittle to ductile deformation: examples from Alpine Corsica and Aegean Sea. Annali di Geofisica 36:139-153.

Jolivet, L. 2001. A comparison of geodetic and finite strain pattern in the Aegean, geodynamic implications. Earth and Planetary Science Letters 187:95-104.

Jones, G. A. \& Keigwin, L. D. 1988. Evidence from Fram Strait $\left(78^{\circ} \mathrm{N}\right)$ for early deglaciation. Nature 336:56-59.

Joughin, I., Alley, R. B. \& Holland, D. M. 2012. Ice-sheet response to oceanic forcing. Science 338:1172-1176.

Jouzel, J., Masson-Delmotte, V., Cattani. O. et al. 2007. Orbital and millennial Antarctic climate variability over the past 800,000 years. Science 317:793-796.
Kapsimalis, V., Pavlakis, P., Poulos, S. E. et al. 2005. Internal structure and evolution of the Late Quaternary sequence in a shallow embayment: The Amvrakikos Gulf, NW Greece. Marine Geology 222-223:399-418.

Karunarathna, H., Reeve, D. \& Spivack, M. 2008. Long-term morphodynamic evolution of estuaries: An inverse problem. Estuarine, Coastal and Shelf Science 77:385-395.

Kastens, K. A. \& Mascle, J. 1990. The geological evolution of the Tyrrhenian Sea: An introduction to the scientific results of ODP Leg 107. In Kastens, K. A., Mascle, J., Aurroux, C. et al. Proceedings of the Ocean Drilling Program, Scientific Results, 107: College Station, TX (Ocean Drilling Program). pp. 3-26.

Kastens, K. A., Mascle, J., Auroux, C. et al. 1988. ODP Leg 107 in the Tyrrhenian Sea: insights into passive margin and back-arc basin evolution. Geological Society of America Bulletin 100:1140-1156.

Kontogianni, V. A., Tsoulos, N. \& Stiros, S. C. 2002. Coastal uplift, earthquakes and active faulting of Rhodes Island (Aegean Arc): Modeling based on geodetic inversion. Marine Geology 186:299-317.

Kossmat, F. 1927. Gliederung des varistischen Gebirgsbaues. Abhandlungen des Sächsischen Geologischen Landesamts 1:1-39.

Kreemer, C. \& Chamot-Rooke, N. 2004, Contemporary kinematics of the southern Aegean and the Mediterranean Ridge. Geophysical Journal International 157:1377-1392.

Lagarde, J. L., Amorese, D., Font, M., Laville, E. \& Dugué, O. 2003. The structural evolution of the English Channel area. Journal of Quaternary Science 18:201-213.

Lambeck, K. 1995. Late Devensian and Holocene shorelines of the British Isles and the North Sea from models of glacio-hydro-isostatic rebound. Journal of the Geological Society 152:437-448.

Lambeck, K. \& Chappell, J. 2001. Sea-level change through the last glacial cycle. Science 292:679686.

Lambeck, K. \& Purcell, A. P. 2001. Sea-level change in the Irish Sea since the Last Glacial Maximum: constraints from isostatic modelling. Journal of Quaternary Science 16:497-506. 
Lambeck, K. \& Purcell, A. 2005. Sea-level change in the Mediterranean Sea since the LGM: model predictions for tectonically stable areas. Quaternary Science Reviews 24:1969-1988.

Lambeck, K. \& Purcell, A. 2007. Palaeogeographic reconstructions of the Aegean for the past 20,000 years: Was Atlantis on Athens' doorstep? In Papamarinopoulos, St. P. (ed.) The Atlantis Hypothesis: Searching for a Lost Land. pp. 241-257. Heliotopos Publications: Santorini.

Lambeck, K., Smither, C. \& Johnston, P. 1998a. Sealevel change, glacial rebound and mantle viscosity for northern Europe. Geophysical Journal International 134:102-144.

Lambeck, K., Smither, C. \& Ekman, M. 1998b. Tests of glacial rebound models for Fennoscandinavia based on instrumented sea- and lake-level records. Geophysical Journal International 135:375-387.

Lambeck, K., Purcell, A., Zhao, J. \& Svensson, N.-O. 2010. The Scandinavian Ice Sheet: from MIS 4 to the end of the Last Glacial Maximum. Boreas 39:410435.

Lambeck, K., Antonioli, F., Anzidei, M. et al. 2011. Sea level change along the Italian coast during the Holocene and projections for the future. Quaternary International 232:250-257.

Lambeck, K., Rouby, H., Purcell, A., Sun, Y. \& Sambridge, M. 2014. Sea level and global ice volumes from the Last Glacial Maximum to the Holocene. Proceedings of the National Academy of Sciences 111:1529615303.

Landvik, J. Y., Bondevik, S., Elverhoei, A. et al. 1998. The last glacial maximum of Svalbard and the Barents Sea area: Ice sheet extent and configuration. Quaternary Science Reviews 17:43-75.

Lauer, A. \& Hamilton, K. 2013. Simulating clouds with global climate models: A comparison of CMIP5 results with CMIP3 and satellite data. Journal of Climate 26:3823-3845.

Lawver, L. A., Dalziel, I. W. D., Norton, I. O. \& Gahagan, L. M. 2009. PLATES 2009 Atlas of Plate Reconstructions (750 Ma to present day). (C) 2009, University of Texas Institute for Geophysics. Available at: www.ig.utexas.edu/research/ projects/plates/recons.htm
Le Pichon, X. \& Angelier, J. 1979. The Hellenic arc and trench system: a key to the neotectonic evolution of the eastern Mediterranean area. Tectonophysics 60:1-42.

Le Pichon, X., Angelier, J. \& Sibuet, J.-C. 1982. Plate boundaries and extensional tectonics. Tectonophysics 81:239-256.

Lericolais, G., Auffret, J-P. \& Bourillet, J. F. 2003. The Quaternary Channel River: Seismic stratigraphy of its palaeo-valleys and deeps. Journal of Quaternary Science 18:245-260.

Lericolais, G., Chivas, A. R., Chiocci, F. L. et al. 2004. Rapid transgressions into semi-enclosed basins since the Last Glacial Maximum. In IGC-IUGS-UNESCO (ed.) 32nd International Geological Congress (Abstracts). $20^{\text {th }}-27^{\text {th }}$ August 2004, Florence, p. 1124.

Lericolais, G., Bulois, C., Gillet, H. \& Guichard, F. 2009. High frequency sea level fluctuations recorded in the Black Sea since the LGM. Global and Planetary Change 66:65-75.

Lericolais, G., Guichard, F., Morigi, C. et al. 2011. Assessment of Black Sea water-level fluctuations since the Last Glacial Maximum. In Buynevich, I., YankoHombach, V., Gilbert, A. \& Martin, R. (eds.) Geology and Geoarchaeology of the Black Sea Region: Beyond the Flood Hypothesis. GSA Special Paper 473:33-50.

Lericolais, G., Bourget, J., Popescu, I. et al. 2013. Late Quaternary deep-sea sedimentation in the western Black Sea: New insights from recent coring and seismic data in the deep basin. Global and Planetary Change 103:232-247.

Long, D., Wickham-Jones, C. R. \& Ruckley, N. A. 1986. A flint artefact from the northern North Sea. In Roe, D. A. (ed.) BAR International Series (No. 296) Studies in the Upper Palaeolithic of Britain and North West Europe. pp. 55-62. British Archaeological Reports: Oxford.

Lykousis, V. 2009. Sea-level changes and shelf break prograding sequences during the last $400 \mathrm{ka}$ in the Aegean margins: Subsidence rates and palaeogeographic implications. Continental Shelf Research 29:2037-2044.

Lykousis, V. \& Anagnostou, C. 1993. Sedimentological and paleogeographic evolution of the Saronic Gulf during the Late Quaternary. Bulletin of the Geological Society of Greece 28(1):501-510 (in Greek). 
Lykousis, V., Sakellariou, D., Moretti, I. \& Kaberi, H. 2007. Late Quaternary basin evolution of the Gulf of Corinth: Sequence stratigraphy, sedimentation, faultslip and subsidence rates. Tectonophysics 440:29-51.

Martínez Catalán, J. R., Arenas, R., Díaz García, F. et al. 2007. Space and time in the tectonic evolution of the northwestern Iberian Massif: Implications for the Variscan belt. Geological Society of America Memoirs 200:403-423.

Martínez-García, P., Soto, J. I. \& Comas, M. C. 2011. Recent structures in the Alboran Ridge and Yusuf fault zones based on swath bathymetry and sub-bottom profiling: evidence of active tectonics. Geo-Marine Letters 31:19-36.

Mascle, J. \& Martin, L. 1990. Shallow structure and recent evolution of the Aegean Sea: A synthesis based on continuous reflection profiles. Marine Geology 94:271-299.

McKenzie, D. P. 1970. Plate tectonics of the Mediterranean region. Nature 226:239-243.

McKenzie, D. 1978. Active tectonics of the AlpineHimalayan belt: the Aegean Sea and surrounding regions. Geophysical Journal International 55:217-254.

Medeiros, B., Stevens, B., Held, I. M. et al. 2008. Aquaplanets, climate sensitivity, and low clouds. Journal of Climate 21:4974-4991.

Meijer, P. T. \& Wortel, M. J. R. 1997. Present-day dynamics of the Aegean region: A model analysis of the horizontal pattern of stress and deformation. Tectonics 16:879-895.

Meschede, M. 2015. Geologie Deutschlands - Einprozessorientierter Ansatz. Springer Spektrum: Berlin Heidelberg.

Meulenkamp, J. E., Wortel, M. J. R., van Wamel, W. A., Spakman, W. \& Hoogerduyn Strating, E. 1988. On the Hellenic subduction zone and the geodynamical evolution of Crete since the late Middle Miocene. Tectonophysics 146:203-215.

Milankovitch, M. 1930. Mathematische Klimalehre und Astronomische Theorie der Klimaschwankungen (Handbuch Klimatologie I A). Gebrüder Borntraeger: Berlin.

Milne, G. A., Davis, J. L., Mitrovica, J. X. et al. 2001. Space-Geodetic Constraints on Glacial Isostatic Adjustment in Fennoscandia. Science 291:2381-2385.
Milne, G. A., Shennan, I., Youngs, B. A. R. et al. 2006. Modelling the glacial isostatic adjustment of the UK region. Philosophical Transactions of the Royal Society (Series A), 364:931-948.

Mitrovica, J. X., Tamisiea, M. E., Davis, J. L. \& Milne, G. A. 2001. Recent mass balance of polar ice sheets inferred from patterns of global sea-level change. Nature 409:1026-1029.

Moreno, X. 2011. Neotectonic and Paleoseismic onshoreoffshore integrated study of the Carboneras fault (Eastern Betics, SE Iberia). PhD Thesis. Universitat de Barcelona, Spain.

Müller, R. D., Sdrolias, M. Gaina, C. \& Roest, W. R. 2008. Age, spreading rates, and spreading asymmetry of the world's ocean crust. Geochemistry, Geophysics, Geosystems 9:Q04006.

Musson, R. M. W. 2007. British Earthquakes. Proceedings of the Geologists' Association 118:305-337.

Neill, S. P., Scourse, J. D., Bigg, G. R. \& Uehara, K. 2009. Changes in wave climate over the northwest European shelf seas during the last 12,000 years. Journal of Geophysical Research 114:C06015.

Neill, S. P., Scourse, J. D. \& Uehara, K. 2010. Evolution of bed shear stress distribution over the northwest European shelf during the last 12,000 years. Ocean Dynamics 60:1139-1156.

Nicholas, W. A., Chivas, A. R., Murray-Wallace, C. V. \& Fink, D. 2011. Prompt transgression and gradual salinisation of the Black Sea during the early Holocene constrained by amino acid racemization and radiocarbon dating. Quaternary Science Reviews 30:37693790 .

Olsen, J., Anderson, J. N. \& Knudsen, M. F. 2012. Variability of the North Atlantic Oscillation over the past 5200 years. Nature Geoscience 5:808-812.

Peltier, W. R. 1998. Postglacial variations in the level of the sea: Implications for climate dynamics and solidEarth geophysics. Reviews of Geophysics 36:603-689.

Peltier, W. R. 2004. Global glacial isostasy and the surface of the ice-age Earth: The ICE-5G (VM2) model and GRACE. Annual Review of Earth and Planetary Sciences 32:111-149.

Peltier, W. R., Shennan, I., Drummond, R. \& Horton B. 2002. On the postglacial isostatic adjustment of the 
British Isles and the shallow viscoelastic structure of the Earth. Geophysical Journal International 148:443-475.

Perissoratis, C., Piper, D. J. W. \& Lykousis, V. 1993. Late Quaternary sedimentation in the Gulf of Corinth: the effects of marine-lake fluctuations driven by eustatic sea level changes. pp. 693-744. Special Publications of the National Technical University of Athens (dedicated to Prof. A. Panagos).

Pettit, P. \& White, M. 2012. The British Palaeolithic: Human Societies at the Edge of the Pleistocene World. Routledge: Abingdon/New York.

Pirazzoli, P. A., Montaggioni, L. F., Saliege, J. F., Segonzac, G., Thommeret, Y. \& Vergnaud-Grazzini, C. 1989. Crustal block movements from Holocene shorelines: Rhodes Island (Greece). Tectonophysics 170:89-114.

Plant, J. A., Reeder, S., Salminen, R. et al. 2003. The distribution of uranium over Europe: geological and environmental significance. Applied Earth Science (Trans. Inst. Min. Metal. B) (vol. 112(3)).

Popescu, I., Lericolais, G., Panin, N., Wong, H. K. \& Droz, L. 2001. Late Quaternary channel avulsions on the Danube deep-sea fan, Black Sea. Marine Geology 179:25-37.

Popescu, I., Lericolais, G., Panin, N., Normand, A., Dinu, C. \& Le Drezen, E. 2004. The Danube submarine canyon (Black Sea): morphology and sedimentary processes. Marine Geology 206:249-265.

Popescu, S. M. 2004. Sea-level changes in the Black Sea region since 14 ka BP. In IGC-IUGS-UNESCO (ed.) 32nd International Geological Congress (vol. 2, part 2) Abstracts. 20 ${ }^{\text {th }}-28^{\text {th }}$ August 2004, Florence, p. 1426.

Popescu, S. M., Head, M. V. \& Lericolais, G. 2003. Holocene Black Sea environments according to palynology. Geological Society of America Abstracts with Programs (vol. 35 (6)). $2^{\text {nd }}-5^{\text {th }}$ November 2003, Seattle, p. 462.

Rahmstorf, R. 2002. Ocean circulation and climate during the past 120,000 years. Nature 419:207-214.

Richter, D. K., Anagnostou, Ch. \& Lykousis, V. 1993. Aragonitishe Whiting-Ablagerungen in Plio-/Pleistozaenen Mergelsequenzen bei Korinth (Griechenland). Zentralblatt für Geologie und Paläontologie Teil 1. 6:675-688.
Rinterknecht, V. R., Clark, P. U., Raisbeck, G. M. et al. 2006. The last deglaciation of the southeastern sector of the Scandinavian ice sheet. Science 311:14491452.

Roelvink, J. A. 2006. Coastal morphodynamic evolution techniques. Coastal Engineering 53:277-287.

Rohling, E. J., Grant, K., Bolshaw, M. et al. 2009. Antarctic temperature and global sea level closely coupled over the past five glacial cycles. Nature Geoscience 2:500504.

Rosentau, A., Muru, M., Kriiska, A. et al. 2013. Stone Age settlement and Holocene shore displacement in the Narva-Luga Klint Bay area, eastern Gulf of Finland. Boreas 42:912-931.

Ruddiman, W. F. 2008. Earth's climate: Past and Future ( $2^{\text {nd }}$ Ed). W. H. Freeman \& Co.: New York.

Ryan, W. B. F., Pitman III, W. C., Major, C. O. et al. 1997. An abrupt drowning of the Black Sea shelf. Marine Geology 138:119-126.

Ryan, W. B. F., Major, C. O., Lericolais, G. \& Goldstein, S. L. 2003. Catastrophic Flooding of the Black Sea. Annual Review of Earth and Planetary Sciences 31:525554.

Sakellariou, D., Lykousis, V., Alexandri, S. et al. 2007a. Faulting, seismic-stratigraphic architecture and Late Quaternary evolution of the Gulf of Alkyonides Basin — East Gulf of Corinth, Central Greece. Basin Research 19:273-295.

Sakellariou D., Rousakis, G., Kaberi, H. et al. 2007b. Tectono-sedimentary structure and Late Quaternary evolution of the north Evia gulf basin, central Greece: Preliminary results. Bulletin of the Geological Society of Greece 40(1):451-462.

Sartori, R. 1990. The main results of ODP Leg 107 in the frame of Neogene to recent geology of periTyrrhenian areas. In Kastens, K.A., Mascle, J., Aurroux, C. et al. Proceedings of the Ocean Drilling Program, Scientific Results, 107: College Station, TX (Ocean Drilling Program). pp. 715-730.

Sartori, R. 2003. The Tyrrhenian back-arc basin and subduction of the Ionian lithosphere. Episodes 26:217221.

Schmidt, G. A., Jungclaus, J. H., Ammann, C. M. et al. 2011. Climate forcing reconstructions for use in PMIP 
simulations of the last millennium (v1.0). Geoscientific Model Development 4:33-45.

Serri, G. 1997. Neogene-Quaternary magmatic activity and its geodynamic implications in the Central Mediterranean region. Annali di Geofisica 40:681703.

Shaw, B., Ambraseys, N. N., England, P. C. et al. 2008. Eastern Mediterranean tectonics and tsunami hazard inferred from the AD 365 earthquake. Nature Geoscience 1:268-276.

Shennan, I., Bradley, S., Milne, G., Brooks, A., Bassett, S. \& Hamilton, S. 2006. Relative sea-level changes, glacial isostatic modelling and ice-sheet reconstructions from the British Isles since the Last Glacial Maximum. Journal of Quaternary Science 21:585-599.

Siddall, M., Pratt, L. J., Helfrich, K. R. \& Giosan, L. 2004. Testing the physical oceanographic implications of the suggested sudden Black Sea infill 8400 years ago. Paleoceanography 19:PA1024.

Siegenthaler, U., Stocker, T. F., Monnin, E. et al. 2005. Stable carbon cycle-climate relationship during the Late Pleistocene. Science 310:1313-1317.

Solanki, S. K., Usoskin, I. G., Kromer, B., Schüssler, M. \& Beer, J. 2004. Unusual activity of the Sun during recent decades compared to the previous 11,000 years. Nature 431:1084-1087.

Soulet, G., Delaygue, G., Vallet-Coulomb, C. et al. 2010. Glacial hydrologic conditions in the Black Sea reconstructed using geochemical pore water profiles. Earth and Planetary Science Letters 296:57-66.

Soulet, G., Ménot, G., Garreta, V. et al. 2011a. Black Sea "Lake" reservoir age evolution since the Last Glacial - Hydrologic and climatic implications. Earth and Planetary Science Letters 308:245-258.

Soulet, G., Ménot, G., Lericolais, G. \& Bard, E. 2011b. A revised calendar age for the last reconnection of the Black Sea to the global ocean. Quaternary Science Reviews 30:1019-1026.

Spada, G. \& Stocchi, P. 2007. SELEN: A Fortran 90 program for solving the "sea-level equation". Computers \& Geosciences 33:538-562.

Stich, D., Mancilla, F. \& Morales, J. 2005. Crust mantle coupling in the Gulf of Cadiz (SW Iberia). Geophysical Research Letters 32:L13306.
Stich, D., Mancilla, F., Pondrelli, S. \& Morales, J. 2007. Source analysis of the February 12th 2007, $\mathrm{M}_{\mathrm{W}}$ 6.0 Horseshoe earthquake: Implications for the 1755 Lisbon earthquake. Geophysical Research Letters 34:L12308.

Stich, D., Martín, R. \& Morales, J. 2010. Moment tensor inversion for Iberia-Maghreb earthquakes 2005-2008. Tectonophysics 483:390-398.

Thorne, J. A. \& Watts, A. B. 1989. Quantitative analysis of North Sea subsidence. The American Association of Petroleum Geologists Bulletin 73:88-116.

Toucanne, S., Zaragosi, S., Bourillet, J. F. et al. 2009. Timing of massive 'Fleuve Manche' discharges over the last 350 kyr: insights into the European ice-sheet oscillations and the European drainage network from MIS 10 to 2. Quaternary Science Reviews 28:12381256.

van den Broeke, M., Bamber, J., Ettema, J. et al. 2009. Partitioning recent Greenland mass loss. Science 326:984-986.

Viti, M., Mantovani, E., Babbucci, D. \& Tamburelli, C. 2011. Plate kinematics and geodynamics in the Central Mediterranean. Journal of Geodynamics 51:190-204.

Waelbroeck, C., Labeyrie, L., Michel, E. et al. 2002. Sea-level and deep water temperature changes derived from benthic foraminifera isotopic records. Quaternary Science Reviews 21:295-305.

Wanner, H., Solomina, O., Grosjean, M., Ritz, S. P. \& Jetel, M. 2011. Structure and origin of Holocene cold events. Quaternary Science Reviews 30:3109-3123.

Ward, I., Larcombe, P. \& Lillie, M. 2006. The dating of Doggerland - post-glacial geochronology of the southern North Sea. Environmental archaeology 11:207218.

Weninger, B., Schulting, R., Bradtmöller, M. et al. 2008. The catastrophic final flooding of Doggerland by the Storegga Slide tsunami. Documentia Praehistorica 35:124.

Westaway, R. 1993. Quaternary uplift of southern Italy. Journal of Geophysical Research: Solid Earth 98(B12):21741-21772.

Woodward, R. S. 1888. On the form and position of the sea level. United States Geological Survey Bulletin 48:87:170. 
Yokoyama, Y., Lambeck, K., De Deckker, P., Johnston, P. \& Fifield, L. K. 2000. Timing of the Last Glacial Maximum from observed sea-level minima. Nature 406:713-716.

Zhang, W. Y., Harff, J., Schneider, R. \& Wu, C. 2010. Development of a modeling methodology for simulation of long-term morphological evolution of the southern Baltic coast. Ocean Dynamics 60:10851114.

Zhang, W. Y., Harff, J. \& Schneider, R. 2011. Analysis of 50-year wind data of the southern Baltic Sea for modelling coastal morphological evolution - a case study from the Darss-Zingst Peninsula. Oceanologia 53:489-518.

Zhang, W. Y., Schneider, R. \& Harff, J. 2012. A multiscale hybrid long-term morphodynamic model for wave-dominated coasts. Geomorphology 149-150:49-61.

Zhang, W. Y., Harff, J., Schneider, R., Meyer, M., Zorita, E. \& Hünicke, B. 2014. Holocene morphogenesis at the southern Baltic Sea: Simulation of multi-scale processes and their interactions for the Darss-Zingst peninsula. Journal of Marine Systems 129:4-18. 